\title{
Üniversite Öğrencilerinin Türkiye'deki Suriyelilere Yönelik Tutumları: Bir Ölçek Geliştirme Çalışması
}

\author{
Hayriye Güleç ${ }^{1}$ \\ Meltem Arslan Karaca \\ Bursa Uludağ Üniversitesi \\ Bursa Uludağ Üniversitesi \\ Gözde Başkaya ${ }^{3}$ \\ Bursa Uludağ Üniversitesi \\ Selçuk Karaca ${ }^{4}$ \\ Bursa Uludağ Üniversitesi \\ Nilay Kahraman ${ }^{5}$ \\ Bursa Uludağ Üniversitesi
}

\begin{abstract}
Özet
$\mathrm{Bu}$ çalışmanın amacı "Suriyelilere Yönelik Tutumlar Ölçeği”ni geliştirmektir. Çalışmanın amacına uygun olarak hazırlanan madde havuzunun psikometrik özellikleri iki çalışmada incelenmiştir. Ölçeğin geçerlik çalışması için açımlayıcı faktör analizi, madde-toplam korelasyonları ve doğrulayıcı faktör analizi uygulanmıştır. Ayrıca, ölçekten yüksek ve düşük puan alan katılımcıların madde puan ortalamaları arasındaki farklar incelenmiştir. İlk çalışmada $(\mathrm{N}=184)$ açımlayıcı faktör analizi ile ölçeğin üç faktörlü olarak toplam varyansın \% 55 'ini açıkladığı̆ gösterilmiştir. İkinci çalışmada $(\mathrm{N}=317)$ yeni maddeler eklenmiş ve ölçeğin geçerliği iki aşamalı olarak verinin rastgele bölünen iki yarısı üzerinde araştırılmıştır. Rastgele seçilen ilk yarıda $(\mathrm{N}=165)$ açımlayıcı faktör analizi ile ölçeğin ilk çalışmadaki üç faktörlü yapısı iki faktöre indirgenmiştir ve toplam varyansın \%56'sını açıklamaktadır. Verinin ikinci yarısında $(\mathrm{N}=152)$ doğrulayıcı faktör analizi çerçevesinde uygulanan açımlayıcı faktör analizi sonuçlarına göre ölçeğin iki faktörlü yapısı veri ile kabul edilebilir düzeyde uyumludur $(\mathrm{CFI}=.914$; $\mathrm{TLI}=.901 ; \mathrm{RMSEA}=.077$; SRMR = .069). Değişim indisleri bir maddenin madde havuzundan çıkarılmasının ve bir maddenin farklı bir faktör altında yer almasının modelin uyumunu iyi düzeye arttırdığını göstermiştir (CFI = .958; TLI = .951; RMSEA = .055; SRMR = .055). İlk faktör "ayrımcllk", ikinci faktör "grup ve birey düzeyinde gerçekçi tehditler" olarak tanımlanmıştır. Tüm test puanının iç tutarlılık güvenirlik katsayısı .92 olarak hesaplanmıştı. Bu çalışma "Suriyelilere Yönelik Tutumlar Ölçeğì”nin güvenilir ve geçerli bir ölçek olduğunu göstermiştir. Çalışmanın bulguları üniversite öğrencilerinin Suriyelilere yönelik tutumlarının örtük ayrımcılık çerçevesinde ifade edilmiş olabileceğine işaret etmektedir.
\end{abstract}

Anahtar kelimeler: Önyargı, ayrımcılık, Suriyeli, tutum, ölçek geliştirme

\begin{abstract}
The aim of the current study was to develop the "Attitudes towards Syrians Scale". An item pool was prepared in accordance with the purpose of the study and its psychometric properties were investigated in two studies with university students. Exploratory factor analysis, item-total correlations and confirmatory factor analysis were performed to investigate the validity of the scale. Besides, item-mean differences between the high and low scoring participants were inspected. In the first study ( $N$ $=184$ ), three factors were identified using exploratory factor analysis accounting for $55 \%$ of the total variance. In the second study $(\mathrm{N}=317)$ new items were added and the validity of the questionnaire was investigated in a two-step process by splitting the sample into two random sub-samples. In the first random split-half $(\mathrm{N}=165)$ using exploratory factor analysis, two factors were identified accounting for $56 \%$ of the total variance. In the second random split-half $(\mathrm{N}=152)$, the fit of the two-factor structure was investigated using exploratory factor analysis conducted within the confirmatory factor analysis framework. The model fit was acceptable $(\mathrm{CFI}=.914 ; \mathrm{TLI}=.901 ; \mathrm{RMSEA}=.077 ; \mathrm{SRMR}=.069)$. The modification indices revealed that deleting one item and reassigning an item under another factor would improve the fit of the model (CFI = .958; TLI = $.951 ; \mathrm{RMSEA}=.055 ; \mathrm{SRMR}=.055$ ). The two factors of the scale were defined as "discrimination" and "realistic group and individual threats", respectively. The Cronbach's Alpha internal consistency coefficient for the total scale score was .92. This study demonstrated the reliability and the validity of the "Attitudes towards Syrian Scale". The results indicated that the attitudes of university students towards Syrians might be expressed in the framework of subtle discrimination.
\end{abstract}

Keywords: Prejudice, discrimination, Syrian, attitude, scale development

Yazışma Adresi: 'Dr. Öğr. Üyesi, Hayriye Güleç, Bursa Uludağ Üniversitesi Fen-Edebiyat Fakültesi, Psikoloji Bölümü, Sosyal Bölümler Binası, Görükle / Bursa, hayriyegulec@uludag.edu.tr, ORC-ID: 0000-0001-9410-430X

${ }^{2}$ Bursa Uludağ Üniversitesi Fen-Edebiyat Fakültesi, Psikoloji Bölümü, Sosyal Bölümler Binası, Görükle / Bursa, meltemkaraca007@ gmail.com, ORC-ID: 0000-0003-1478-4064

${ }^{3}$ Bursa Uludağ Üniversitesi Fen-Edebiyat Fakültesi, Psikoloji Bölümü, Sosyal Bölümler Binası, Görükle / Bursa, gozdebaskaya07@ gmail.com, ORC-ID: 0000-0002-5538-3550

${ }^{4}$ Bursa Uludağ Üniversitesi Fen-Edebiyat Fakültesi, Psikoloji Bölümü, Sosyal Bölümler Binası, Görükle / Bursa, selcukkaraca0113@ gmail.com, ORC-ID: 0000-0002-1121-4763

${ }^{5}$ Bursa Uludağ Üniversitesi Fen-Edebiyat Fakültesi, Psikoloji Bölümü, Sosyal Bölümler Binası, Görükle / Bursa, nilaykahraman94@ gmail.com, ORC-ID: 0000-0003-1590-0290

Gönderim Tarihi: 01.04.2019

Kabul Tarihi: 10.01.2021 
Suriye'de Arap Baharını takiben başlayan protestolar zaman içinde demokratik bir eksen değişimi yerine iç savaşla sonuçlanan ve uluslararası aktörlerin temsili savaşına sahne olan karmaşık bir insani krize dönüşmüştür (Goldewijk, 2017; Hinnebusch, 2019). Bu süreçte Suriyeliler zorunlu olarak yerlerinden edilmişlerdir ve kendi ülkelerini terk ederek başka ülkelere göç etmek zorunda kalmışlardır. İç savaşın ve akabindeki zorunlu göçün sonucu olarak ortaya çıkan mülteci krizinde en yoğun göç alan ülke Türkiye olmuştur. Birleşmiş Milletler Mülteciler Yüksek Komiserliği (United Nations High Commissioner for Refugees [UNHCR]) 19 Temmuz 2018 verilerine göre Türkiye'deki Suriyeli sığınmacı sayıs1 3.541.572 olarak bildirilmektedir.

Ev sahibi ülkelerde göçmenlere veya mültecilere yönelik tutumlar, gruplar arası ilișkilerde grup üyeliğinin rolünü vurgulayan teorik bakış açısıyla açıklanmaktadır. Sosyal kimlik kuramı iç grup ile dış grup arasındaki k1yaslamalarda kişinin kendini ait hissettiği grubu olumlu değerlendirerek ve dış grup üyeleri ile arasındaki farklılıkları vurgulayarak kendilik değerini artırdığını öne sürmektedir (Tajfel ve Turner, 2004). Ayrıca, çoğunluk konumunda bulunan iç grup üyelerinin azınlık konumundaki dış grup üyelerini daha homojen olarak algılayarak kendi kimlikleri ile diğerleri arasındaki ayrışmayı belirginleştirdikleri düşünülmektedir (Park \& Rothbart, 1982). Sosyal baskınlık kuramı toplulukların hiyerarşik yapıda olduğunu vurgulamaktadır (Sidanius ve Pratto, 2004). Baskın olan grupların statü, güç ve kaynaklara erişim gibi pozitif sosyal değerleri kaybetmemek için kendi iç gruplarını kayırıp dış gruptakileri küçülterek var olan hiyerarşiyi sürdürme eğiliminde oldukları düşünülmektedir (Sidanius ve Pratto, 2004). Gruplar arası Tehdit Kuramı iç grup üyelerinin diş gruba yönelik önyargısını evrimsel açıdan açıklamaktadır (Stephan, Ybarra ve Rios, 2016). İnsanların kabileler halindeki yaşam biçimi ortak gelenek, alışkanlıklar, dil, söylenceler, din ve ihtiyaçların karşılanması aracılığıyla önem kazanmış ve üyesi olunan kabilenin sınırları dışında yer alan ve diğerlerinden oluşan kabilelerin tehdit olarak algılanması ile sonuçlanmıştır (Stephan, Ybarra ve Rios, 2016). Gerçekçi ve sembolik olmak üzere tanımlanan tehdit faktörleri olumsuz duygular ve basmakalıp inançlar aracılığıyla dış gruba yönelik önyargıya neden olmaktadır (Stephan, Renfro ve Davis, 2008). Gerçekçi tehditler iç grubun ekonomik ve politik üstünlüğüne ya da fiziksel iyi oluşuna yönelik tehditler iken sembolik tehditler gruplar arasındaki değer, norm, standart, ahlak, inanç ve tutum farklarından kaynaklanan tehditlerdir (Stephan, Renfro ve Davis, 2008).

Önyargılı tutum dış grup üyelerinin açık ya da örtük şekilde ayrımcılığa uğraması ile sonuçlanmaktadır (Dovidio, Gaertner ve Pearson, 2016). İç grup üyeleri- nin kendi 1rkını diğer 1rktaki insanlardan üstün görmesi ve kendi ırkından olmayanların eşit hak ve özgürlüklere sahip olmasına açık bir dille karşı çıkması ırka dayalı ayrımcılığın açık ifadesidir (Pettigrew ve Meertens, 1995). Kaçınmacı 1rkçılık ırka dayalı ayrımcılığın örtük ifadesini tanımlamak için kullanılmaktadır ve ilk olarak Amerika'daki beyazların zencilere yönelik tutumlarını tanımlamak üzere önerilmiştir (Dovidio ve Gaertner, 2004). Fakat daha sonraki çalışmalar örtük ayrımcılığın farklı toplumlarda avantajlı ve dezavantajlı konumda bulunan gruplar arasında da geçerli olduğunu ve sadece ırka dayalı olarak gerçekleşmediğini göstermiştir (Dovidio, Gaertner, Nier ve Hodson, 2005; Pearson, Dovidio ve Gaertner, 2009). Örtük ayrımcılık, öz-bildirime dayalı ölçümlerde dezavantajlı olan grupların uğradıkları adaletsizliklere sempati duyup, grupların eşitliliğini vurgulayan değerlere bağlı olduklarını ifade eden iç grup üyelerinin örtük olarak deneyimledikleri olumsuz duygu ve düşünceler nedeniyle gerçekte önyargılı olmayan iç grup üyelerine kıyasla daha ayrımcı olmaları ile açıklanmaktadır (Hodson, Hooper, Dovidio ve Gaertner, 2005). Örneğin, göçmenlerin Avrupa'ya alınmasına karşı çıkılması açık ayrımcılık iken ön koşul olarak belli bir eğitim düzeyinin zorunlu hale getirilmesi görünürde açık olmayan örtük ayrımcılık ile ilişkilidir (Dovidio, Gaertner, Nier ve Hodson, 2005; Pettigrew ve Meertens, 1995).

Gruplar arası kaygı ve sosyal baskınlık eğilimi dış gruba yönelik önyargı ve ayrımcılıkla ilişkilidir. Gruplar arası kaygı duygu, biliş ve fizyoloji bileşenlerini içeren ve diş grupla etkileşim sırasında deneyimlenen rahatsızlık olarak tanımlanmaktadır (Stephan, 2014). Duygu bileşeni endişe, sıkıntı ve rahatsızlık duyguları, fizyoloji bileşeni etkileşim sırasında gerçekleşen fizyolojik uyarılma, biliş bileşeni ise etkileşimin olumsuz sonuçlanacağ1 yönündeki beklentiler ile ilişkilidir (Stephan, 2014). Etkileşimin olumsuz sonuçları dış grup tarafindan kabul edilmemek veya iç grup tarafından dişlanmak şeklinde olabilir ya da kişide fiziksel veya psikolojik zarar geleceğine dair olumsuz beklentiler nedeniyle deneyimlenmektedir (Stephan ve Stephan, 1985). Kaygının duygu, biliş ve fizyoloji düzeyinde deneyimlenen üç bileşeni birbiriyle yakından ilişkilidir. Kaygı nedeniyle deneyimlenen olumsuz duygular davranış düzeyinde dış gruba yönelik olumsuz ve ayrımcılığa neden olan davranışlarla sonuçlanmaktadır (Stephan, 2014). Diş gruptan kaçınma, dış gruba yönelik savunmacı tutum ve daha düşük düzey yardım etme davranışları olarak gösterilen bu davranışlar kısır döngüye yol açarak deneyimlenen kaygının sönmesini engellemektedir (Stephan, 2014).

Sosyal baskınlık eğilimi iç grubun dış grup üzerindeki gücünü baskınlık ve hiyerarşi yoluyla sağlamasına yönelik genel bir yatkınlıktır (Sidanius ve Pratto, 2004). Bireysel bir değişken olarak tanımlanmasının yanında 
gruplar arası etkileşimde önyargılı ve ayrımcılığa dayalı tutumları açıklamak için de kullanılmaktadır (Sidanius ve Pratto, 2004). Bu eğilimin baskınlık ve eşitlik olmak üzere iki boyutu vardır (Hindriks, Verkuyten ve Coenders, 2014): Baskınlık boyutu iç grubun dış grup üzerinde ezerek ya da güç kullanarak baskı ve hükümranlık kurmak istemesi ile ilişkilidir. Eşitlik boyutu ise grupların eşit olduğu ve eşit haklara sahip olması gerektiği yönündeki prensibe karşı çıkılması ile ilişkilidir (Hindriks, Verkuyten ve Coenders, 2014).

Göçmenler ve mülteciler çoğunlukla homojen gruplar olarak algılanmaktadır ve ev sahibi ülkelerdeki kişilerin göçle ilgili tutumlarına ilişkin bulguların sıklıkla gruplar arasında genellenebileceği varsayılmıştır (Finney ve Peach, 2004; Schweitzer, Perkoulidis, Krome, Ludlow ve Ryan, 2005). Murray ve Marx (2013) Amerika-Meksika sınır bölgesinde yürüttükleri bir çalışmada Amerikalıların yasal yollarla ülkeye giren göçmenlere ve sığınma talebinde bulunan kişilere yönelik tutumlarının kaçak olarak ülkeye giren göçmenlere kıyasla daha olumlu olduğunu göstermişlerdir. Bir başka çalışmada Türkiye'deki göçmen ve mülteci statüsündeki kişilere yönelik tutumların gruplar arası kaygı ve patojene bağlı iğrenme duyguları ile olan ilişkisi araştırılmıştır (Aral, Sevi ve Aydinli-Karakulak, 2016). Gruplar arası kaygı hem göçmen hem de mültecilere yönelik tutumlarla ilişskili iken patojene bağlı iğrenme sadece mültecilere yönelik tutumlarla ilişkili bulunmuştur. Bu bulgular grupların statü ve ülke değiştirme konusundaki konumlarının tutumları etkileyebileceğine işaret etmektedir (Murray ve Marx, 2013).

Türkiye dünyada en fazla mülteci barındıran ülke konumundadır (UNHCR, 2018). Suriyeliler Birleşmiş Milletlerin (2006) kabul ettiği mülteci statüsünde değil misafir ya da sığınmacı statüsünde Türkiye'ye kabul edilmiştir (Ekmekci, 2017). Fakat iç savaşın uzaması ve insani bir krizin ortaya çıkması nedeniyle "misafir" olarak tanımlanmış olan statüleri kalıcı hale gelmiştir (International Crisis Group, 2016). Suriyelilerin Türkiye'deki konumlarına ve bütünleşmelerine ilişkin tutumlar çogunlukla kamuoyu yoklamalarından ve derinlemesine yapılan görüşmelerden elde edilen bulgulara dayanmaktadır. Hacettepe Üniversitesi Göç Araştırmaları Merkezi tarafından 11 ilde yürütülen bir çalışmada katılımcıların yarıya yakını (\%45.1) Suriyelilerin ülkelerine geri dönmelerini beklediğini, çoğunluğu (\%76.5) Suriyeli sığınmacıların ülkede kalmasının toplumsal açıdan büyük bir soruna neden olacağını belirtmiştir (Erdoğan, 2014). Suriyeli sığınmacılara vatandaşlık hakkı tanınması (\%84.5) reddedilen konuların başında gelmiştir (Erdoğan, 2014). Orta Doğu Stratejik Araştırmalar Merkezi'nin 2015 raporunda yerel halkın uyum sürecinde başlıca olumsuz tutumlarının Suriyeli sığınmacıların dil, kültür ve yaşam tarzı farklılıkları, toplum huzur ve asayişin bozulduğuna ilişkin tedirginlik, iş imkanlarının kısıtlanması ve özellikle sağlık hizmetleri olmak üzere temel hizmetlerde yaşanan kapasite ve hizmet sorunları olduğu görülmüştür (Orhan ve Senyücel Gündoğan, 2015).

Kamuoyu yoklamaları, Türkiye'de Suriyelilere yönelik tutumların olumsuz olduğunu gösterse de bu bulguların sistematik olarak değerlendirilmesine ihtiyaç vardır. Sosyal ve politik psikoloji alanında dış gruba yönelik tutumların sabit, tüm sosyal bağlamlar için geçerli olan ve davranışın koşulsuz belirleyicisi olarak kabul edilmesinin ya da sosyal bir bağlamın her zaman dış gruba yönelik aynı tutumlarla sonuçlanacağının varsayılmasının hatalı bir çıkarım olacağı vurgulanmaktadır (Reicher, 2004). Türkiye'de Suriyelilere yönelik tutumlarla ilişkili olabilecek bazı bağlamsal özellikler dikkati çekmektedir. İlk olarak, Türkiye Suriyelilerin gelmesiyle birlikte dünyada en fazla mülteciye ev sahipliği yapan ülke konumuna gelmiştir (UNHCR, 2018). Suriyeliler misafir ya da sığınmacı olarak kabul edilseler de zamanla kalıcı hale gelmişlerdir. Misafir konumundan kalıcı konuma geçilen süreçte zorunlu göçün ilk yıllarındaki olumlu tutum olumsuz yöne doğru kaymış ve yerel halkın Suriyelilere eğitim ve sağlık alanlarında sağlanan haklardan rahatsızlık duymaya ve Suriyelilerin ülkedeki barış ve güveliği tehdit ettiğini düşünmeye başladığı bir değişimi başlatmıştır (Yıldız Nielsen, 2016). Ayrıca yerel halk ile Suriyeliler arasındaki etkileşim ve beklentiler sıklıkla medya ve iletişim alanlarında görünür hale gelmiş ve sıklıkla gruplar arası çatışmanın öne çıkarıldığı şekilde sunulmuştur (Göker ve Keskin, 2015; Pandır, Efe ve Paksoy, 2015). Suriyelilere yönelik tutumların bu bağlam içinde nasıl şekillendiğini araştıran çalışmalar kısıtlıdır. Literatürde Suriyelilere yönelik tutumları araştırmak amacıyla geliştirilen ölçekler incelendiğinde, çoğunlukla Türkiye bağlamını yakalamak için tasarlanan maddeler yerine genel olarak göçmenlere yönelik tutumları ölçmek için geliştirilen ölçek maddelerinin kullanıldığ1 görülmektedir (Keleş, Aral, Yıldırım, Kurtoğlu ve Sunata, 2016). Ayrıca, ölçeklerin madde içeriğinin ve faktör yapısının kavramsal olarak değerlendirilmesi çoğunlukla eksik kalmıştır (Kılcan, Çepni ve Kılınç, 2017; Köksal, Köksal ve Köksal, 2017). Türkiye'deki Suriyelilere yönelik tutumların Türkiye bağlamında öne çıkan konular dikkate alınarak araştırılmasının iki açıdan literatüre katkı sağlayacağı düşünülmektedir. İlk olarak, böyle bir ölçekten elde edilen faktör yapısı ve madde içerikleri tutumlarla ilişkili sosyal psikolojik değişkenlerle ilişkilendirilebilir ve tutumları belirleyen değişkenlerin veriye dayalı olarak çalışılmasını sağlayarak kuramsal çalışmalara katkı sağlayabilir. İkinci olarak, çalışmanın bulguları gruplar arası etkileşimde önyargı ve ayrımcılığın azaltılmasında bağlama özgü müdahale programlarının geliştirilmesine yardımcı olabilir. 
$\mathrm{Bu}$ çalışmanın amacı "Suriyelilere Yönelik Tutumlar Ölçeği”ni geliştirmektir. Bu amaçla, Suriyeli mültecilerin Türkiye'deki uyum ve bütünleşme konuları hakkında yerel halkın tutumları ile ilgili bir madde havuzu hazırlanmış ve üniversite öğrencileriyle yapılan iki çalışmada ölçeğin psikometrik özellikleri incelenmiştir. Ölçek maddeleri sosyal bağlamı yansıtması amacıyla kamuoyu yoklamaları ve yerel ve ulusal basındaki sözlü ve yazılı haberler dikkate alınarak belirlenmiştir. Ölçeğin faktör yapısı ve madde içerikleri sosyal psikolojik değişkenler ile ilişkilendirilerek Türkiye bağlamında üniversite öğrencilerinin Suriyelilere yönelik tutumlarının sistematik olarak araştırılması hedeflenmiştir.

\section{Çalıșma I}

\section{Yöntem}

Katılımcılar ve işlem. Bu çalışmaya 2015-2016 akademik yılında Bursa Uludağ Üniversitesi'nde eğitimine devam eden öğrenciler katılmıştır $(\mathrm{N}=191)$. Üç katılımcının formu eksik doldurması, iki katılımcının Bursa Uludağ Üniversitesi öğrencisi olmaması ve iki katılımcının sorulara birden fazla cevap vermesi nedeniyle yedi katılımcının verisi değerlendirmeye alınmamıştır. Araştırmanın örneklemi 184 katılımcıdan oluşmaktadır (Kadın: 101; Erkek: 83). Katılımcıların yaş ortalaması 21.94 'tür $(\mathrm{S}=2.75$; yaş aralığ $1=18-34)$. Çalışma için etik onay Bursa Uludağ Üniversitesi Sosyal ve Beşerî Bilimler Etik Kurulu tarafından verilmiștir.

Suriyelilere Yönelik Tutumlar Ölçeği. Yapılan literatür taraması ve yerel-ulusal basında çıkan yazılı ve sözlü haberlerin incelenmesi sonucu 45 maddelik bir madde havuzu oluşturulmuştur. İlk tarama sonrasında benzer olduğu düşünülen on madde ile tutumu ölçmediğine karar verilen bir madde çıkarılmıştır. Ayrıca, iki maddenin anlaşılır olmadığı düşünülüp ifade değişikliği yapılmıştır. $\mathrm{Bu}$ işlem sonunda 12 'si olumlu 22 'si olumsuz tutum ifadesi olan 34 madde kabul edilmiştir. Maddelerin içeriği kabul ve uyum, eğitim, ekonomi ve sağlık alanlarını içermektedir. Maddeler birinci tekil kişi dilinde yazılmıştır ve dış grubu belirginleştirerek (Suriyeliler) bireysel düzeydeki tutumların belirlenmesi hedeflenmiştir. Madde havuzunun kapsam geçerliliğini tespit etmek amaciyla yedi uzman psikolog, iki psikoloji bölümü akademisyeni ve bir sosyolog olmak üzere 10 kişiden görüş alınmıştır. Lawshe (1975) tarafından önerilen kapsam geçerlik oranı formülü kullanılarak madde havuzundan sekiz madde daha çıkarılmıştır. Böylelikle madde havuzu 6's1 olumlu 20'si olumsuz tutumu ifade eden 26 maddeye indirilmiştir. Ayrıca kapsam geçerlik oranı değerleri dikkate alınarak bazı maddelerin ifadesinde değişiklik yapılmıştır. $\mathrm{Bu}$ işlemin ardından mad- delerin anlaşılır olup olmadığını kontrol etmek amacıyla Bursa Uludağ Üniversitesi'nde eğitimine devam eden 25 psikoloji bölümü öğrencisine ön uygulama yapılmıştır. Ön uygulama sonucunda bir madde çıkarılmış ve dört maddenin içeriği daha anlaşılır olacak şekilde tekrar yazılmıştır. Oluşturulan madde havuzu 8'i olumlu 17'si olumsuz yönde tutumu ölçen 25 maddeden oluşmaktadır. Katılımcılardan beş noktalı Likert tipi ölçekte ("Kesinlikle katılmıyorum" "Katılmıyorum", "Kararsızım", "Katıliyorum", "Kesinlikle katılıyorum") maddelere katılma düzeylerini belirtmeleri istenmiştir. Ölçekten en az 25, en fazla 125 puan alınmaktadır. Ölçekten alınan puan yükseldikçe olumsuz tutum artmaktadır.

İstatistiksel analiz. Ölçeğin güvenirliği iç tutarlık güvenirlik katsayısı ile hesaplanmıştır. Faktör analizinden önce madde-toplam korelasyon katsayısı .30'un altında olan maddeler madde havuzundan çıkarılmıştır. Ölçeğin faktörlü bir yapıda olup olmadığını değerlendirmek amacıyla varimaks eksen döndürmesi ve temel bileşenler yöntemi kullanılarak açımlayıcı faktör analizi uygulanmıștır. Verinin faktör analizine uygun olup olmad1ğını değerlendirmek için Barlett ve Kaiser-Meier-Olkin (KMO) test sonuçları incelenmiştir. Buna göre, KMO katsayısının 90 üzerinde olması ve Barlett test değerinin $\mathrm{p}<.001$ düzeyinde anlamlı olması gerekmektedir (Bartlett, 1950; Kaiser ve Rice, 1974). Analizlerde faktör yükü .40 ve üzerinde olan maddeler havuzda tutulmuştur. Ayrıca, faktör yükü .40 ve üzerinde olup birden çok faktör altında yer alan maddelerde faktör yükleri arasındaki farkın .10'dan küçük olduğu maddeler çıkarılmıştır. Analizler SPSS programı kullanılarak gerçekleştirilmiştir (IBM, 2015).

\section{Bulgular}

Madde-toplam korelasyon katsayısı .30'un altında olan bir madde çıkarıldıktan sonra hesaplanan iç tutarlılık güvenirlik katsayısı .94 olarak bulunmuştur. Veri faktör analizine uygundur (KMO $=.936$ ve Barlett testi istatistiği $\left.\chi^{2}(184)=2191.53, \mathrm{p}<.001\right)$. Rotasyondan sonra özdeğeri (eigen value) birden büyük olan üç faktör olduğu görülmüştür. Birinci faktör varyansın yaklaşık olarak \%23'ünü, ikinci faktör yaklaşık olarak \%22'sini ve üçüncü faktör yaklaş1k olarak \%8'ini açıklamaktadır. Açıklanan toplam varyans \%53.6 olarak hesaplanmıştır.

Birden çok faktör altında yer alan ve faktör yükleri arasındaki farkın .10'dan küçük olduğu dört madde çıkarıldıktan sonra yirmi maddelik madde havuzuna tekrar faktör analizi uygulanmıştır $(\mathrm{KMO}=.935$; Barlett testi istatistiği, $\left.\chi^{2}(184)=1682.45, \mathrm{p}=.000\right)$. Özdeğeri birden büyük olan üç faktör bulunmuştur. Rotasyondan sonra birinci faktör varyansın yaklaşık olarak \%20'sini, ikin- 
Tablo 1. "Suriyelilere Yönelik Tutumlar Ölçeği” Maddeleri, Faktör Yükleri, Açıklanan Varyans Yüzdeleri, Özdeğerler, Madde-Toplam Korelasyonları ve İç Tutarlılık Katsayısı Değerleri $(N=184)$ (Çalışma I)

\begin{tabular}{|c|c|c|c|c|}
\hline Ölçek maddeleri & Faktör 1 & Faktör 2 & Faktör 3 & $\begin{array}{l}\text { Madde-Toplam } \\
\text { Korelasyonu }\end{array}$ \\
\hline Suriyeli bir sığınmacı ile arkadaş olmak isterim. ${ }^{R}$ & .73 & .27 & .21 & .68 \\
\hline Suriyelilerin açtığı dükkândan alışveriş yapabilirim. ${ }^{R}$ & .67 & .24 & .32 & .68 \\
\hline Suriyelilere yönelik olumsuz tepkileri acımasızca buluyorum. ${ }^{R}$ & .65 & .09 & .21 & .52 \\
\hline Suriyeli sığınmacılar için yeterli eğitim imkânları sunulmalıdır. ${ }^{\mathrm{R}}$ & .63 & .25 & .08 & .53 \\
\hline Bir Suriyeli ile komşu olmak beni rahatsız eder. & .60 & .28 & .28 & .63 \\
\hline $\begin{array}{l}\text { Her ne olursa olsun (savaş hali de dahil olmak üzere) Suriyeli } \\
\text { sığınmacilar ülkelerine zorla geri gönderilmelidir. }\end{array}$ & .60 & .04 & .28 & .49 \\
\hline Suriyeliler ile aynı sınıfta eğitim görmekten rahatsız olurum. & .59 & .40 & .00 & .61 \\
\hline Suriyeli sığınmacılar çalışma hayatına dâhil edilmelidir. ${ }^{\mathrm{R}}$ & .54 & .40 & .00 & .52 \\
\hline Suriyeli sığınmacılar T.C. vatandaşlığına alınmamalıdır. & .17 & .71 & .11 & .52 \\
\hline $\begin{array}{l}\text { Suriyeli sığınmacıların yerel halkın iş imkânlarını kısıtlandığını } \\
\text { düşünüyorum. }\end{array}$ & .24 & .66 & .41 & .71 \\
\hline $\begin{array}{l}\text { Türk işveren ve işçiler vergi verirken Suriyeli işveren ve } \\
\text { işçilerin vergi vermemesi yanlış bir uygulamadır. }\end{array}$ & .07 & .63 & .06 & .40 \\
\hline $\begin{array}{l}\text { Suriyeli sığınmacıların kamplar dışındaki yerlerde ikamet } \\
\text { etmesinde sakınca görmüyorum. }{ }^{R}\end{array}$ & .37 & .59 & .23 & .65 \\
\hline $\begin{array}{l}\text { Ülkemizdeki fakirlere harcanması gereken paranın Suriyelilere } \\
\text { harcanmasını doğru bulmuyorum. }\end{array}$ & .32 & .60 & .36 & .69 \\
\hline $\begin{array}{l}\text { Suriyeli sı̆̆ınmacılar ülkemizde misafir olduklarının farkında } \\
\text { olmalı ve buna göre davranmalılar. }\end{array}$ & .15 & .58 & .18 & .48 \\
\hline $\begin{array}{l}\text { Suriyeli sığınmacıların ülkemizde uzun süre kalacak olması } \\
\text { beni rahatsız etmez. }{ }^{\mathrm{R}}\end{array}$ & .32 & .57 & .43 & .72 \\
\hline Suriyeli sığınmacılarla birlikte suç oranları artmıştır. & .13 & .21 & .78 & .56 \\
\hline $\begin{array}{l}\text { Suriyeli sı̆̆ınmacıların ülkemize gelmesi ile birlikte toplum } \\
\text { huzuru ve düzeni bozulmuştur. }\end{array}$ & .31 & .33 & .70 & .71 \\
\hline $\begin{array}{l}\text { Suriyeli sığınmacı sayısının fazlalığından dolayı sağlık } \\
\text { hizmetlerinin aksaması beni öfkelendirir. }\end{array}$ & .26 & .43 & .62 & .69 \\
\hline $\begin{array}{l}\text { Suriyeli sığınmacıların kamplardaki yaşam standartlarının } \\
\text { arttırılmasını gereksiz buluyorum. }\end{array}$ & .30 & .04 & .59 & .48 \\
\hline $\begin{array}{l}\text { Sığınmacıların ülkemizi, mahallelerimizi ve sokaklarımızı } \\
\text { doldurmalarından dolayı kendimi sürekli tehdit altında } \\
\text { hissediyorum. }\end{array}$ & .46 & .35 & .55 & .74 \\
\hline Açıklanan Varyans (\%) & 20.47 & 18.2 & 15.9 & \\
\hline Özdeğer & 4.09 & 3.64 & 3.18 & \\
\hline İç Tutarlılık Katsayısı & .85 & .84 & .83 & \\
\hline
\end{tabular}

Not. Maddeler ilişkili oldukları faktörler altında kalın yazı tipiyle gösterilmiştir. ${ }^{\mathrm{R}}$ Ters yönde puanlanan madde.

ci faktör varyansın yaklaşık olarak \%18'ini ve üçüncü faktör varyansın yaklaşık olarak \%16'sını açıklamıştır. Açıklanan toplam varyans \%54.56 olarak hesaplanmıştır. Faktör yükleri .54 ile .78 arasında değişmektedir ve 7 madde ters yönde puanlanmaktadır. Toplam puan için hesaplanan iç tutarlılık güvenirlik katsayısı .93’tür. Maddeler, faktör yükleri, madde-toplam korelasyonları, varyans yüzdeleri, özdeğerler ve her faktör için hesaplanan iç tutarlılık güvenirlik katsayıları Tablo 1'de gösterilmektedir. 


\section{Tartıșma}

Bu çalışmada "Suriyelilere Yönelik Tutumlar Ölçeği'nin açımlayıcı faktör analizi ile üç faktörlü olarak açıklanabileceği ve ölçek maddelerinin toplam varyansın \%55'ini açıkladığı gösterilmiştir.

Çalışmanın amacına uygun olarak, ölçeğin faktör yapısı ve madde içerikleri sosyal psikolojik değişkenler ile ilişkili olarak açıklanmıştır. İlk faktörün gruplar aras1 kayg1 ve sosyal baskınlık eğilimi ile ilişkili maddelerden oluştuğu düşünülmektedir. Suriyelilerle temasta olmaktan duyulan rahatsızlık ile ilişkili maddelerin ("Suriyeliler ile aynı sınıfta eğitim görmekten rahatsız olurum.", "Bir Suriyeli ile komşu olmak beni rahatsız eder") gruplar arası kaygının duygu bileşenini temsil ettiği düşünülmektedir (Stephan, 2014). Suriyelilerle ilişki kurmaktan kaçınma düzeyi ile ilgili maddeler ise ("Suriyeli bir sı̆̆ınmacı ile arkadaş olmak isterim", "Suriyelilerin açtığı dükkândan alışveriş yapabilirim") davranış düzeyinde deneyimlenen gruplar arası kayg1 ile ilişkili bulunmuştur (Stephan, 2014). Suriyelilerin iş ve eğitim koşullarının iyileştirilmesi ile ilgili maddelerin ("Suriyeli sığınmacılar için yeterli eğitim imkânları sunulmalıdır" ve "Suriyeli sı̆̆ınmacılar çalışma hayatına dâhil edilmelidir") sosyal baskınlık eğiliminin eşitlik boyutu ile açıklanabileceği düşünülmektedir (Hindriks, Verkuyten ve Coenders, 2014). Bu maddelerde olumlu yönde tutum sergilenmesinin Suriyelilerin sosyal statü açısından eşitler olarak algılandığı temas miktarını artıracağı düşünülmektedir. Öte yandan olumsuz yöndeki tutum eşit olmayan statü ilişkileri aracılığıyla Suriyelilerin ayrımcılığa uğramasına neden olabilir. "Suriyelilerin ülkeden zorla gönderilmeleri" ile ilişkili madde baskıya dayalı olarak güç kullanılması açısından, "Suriyelilere yönelik olumsuz tepkilere duyarsız kalınması" ile ilişkili madde ise gruplar arasındaki hiyerarşiyi koruması açısından sosyal baskınlık eğiliminin baskınlık boyutu ile ilişkili bulunmuştur (Hindriks, Verkuyten ve Coenders, 2014). Gruplar arası kaygı dış gruptan kaçınmaya ve sosyal mesafeye (Stephan, Ybarra ve Rios, 2016), sosyal baskınlık eğilimi ise dış gruba yönelik eşitlik karşıt1 ve iç grubun üstünlüğünü korumaya yönelik davranışlara neden olmaktadır (Sidanius ve Pratto, 2004). Davranış düzeyindeki sonuçları dikkate alınarak ilk faktörün ölçtüğü kavram "ayrımcılık" olarak tanımlanmıştır.

Ölçeğin ikinci ve üçüncü faktörlerinin gerçekçi tehditler ile ilişkili olduğu düşünülmektedir. Gruplar Arası Tehdit Kuramına göre gerçekçi tehditler gruplar arası ve bireysel düzeyde gerçekleşmektedir (Stephan, Renfro ve Davis, 2008). İç grubun güç mesafesine, kaynaklara erişimine ve iyi oluşuna yönelik algılanan tehditler grup düzeyindeki gerçekçi tehditler olarak ta- nımlanmıştır. Bireysel düzeydeki gerçekçi tehditler ise iç grubun bireysel üyelerine yönelik algılanan tehditler ve sonuçları ile ilgilidir. İkinci faktör altında yer alan "Suriyeli sığınmacılara vatandaşlık hakkı tanınması" ile ilgili madde iç grubun güç mesafesine ve politik anlamdaki üstünlüğüne, "istihdamın ve maddi kaynakların dağılımındaki değişiklikler" ve "vergi muafiyeti" ile ilgili maddeler ise iç grubun ekonomik üstünlügüne yönelik algılanan gerçekçi tehditler ile ilişkili bulunmuştur. Bu maddelerdeki tehdit algısının grup düzeyinde gerçekleştiği düşünülmektedir ve "grup düzeyinde gerçekçi tehditler” olarak tanımlanmıştır. Üçüncü faktör güvenlik, birlikte yaşama ve hizmetlerin işleyişi konusundaki tutumları değerlendiren ve iyi oluşa yönelik tehdit alg1sı ile ilgili maddelerden oluşmaktadır. Bu maddelerdeki tehdit algısının tehdidin bireysel düzeydeki sonuçları ile ilişkili olduğu düşünülmektedir ("Sığınmacıların ülkemizi, mahallelerimizi ve sokaklarımızı doldurmalarından dolayı kendimi sürekli tehdit altında hissediyorum"). Bu faktör "birey düzeyinde gerçekçi tehditler" olarak tanımlanmıştır.

\section{Çalışma II}

Daha önceki çalışmalarda sembolik düzeyde algilanan tehditlerin (Stephan, Ybarra ve Rios, 2016) ve kültürel çeşitlilik konusundaki tutumların (Verkuyten, 2006) önyarg1 ve ayrımcılıkla ilişkili olduğu rapor edilmiştir. Bu değişkenlerin Suriyelilere yönelik tutumlarla ilişkisi hakkında daha fazla bilgi edinmek ve ölçeğin faktör yapısını tekrar değerlendirmek amacıyla ikinci bir çalışmanın yapılmasına karar verilmiştir. Bunun için madde havuzuna iki yeni madde eklenmiştir ("Suriyeli sığınmacılar yerel halkın yaşam tarzını ve değerlerini tehdit etmektedir", "Suriyeli sığınmacıların kültürel çeşitlilik açısından bir firsat olduğunu düşünüyorum"). Ayrıca, gerçekçi tehditlerin gruplar arası ve bireysel düzeyde ayrışıp ayrışmadı̆̆ı konusunda daha fazla bilgi edinmek amaciyla hizmetlerin aksaması ile ilişkili bir madde eklenmiştir ("Suriyeli sığınmacıların fazlalığından dolayı verilen hizmetler aksamaktadır"). Ölçek yedisi olumlu 16's1 olumsuz yönde tutum ifadesini içeren 23 maddeden oluşmaktadır.

\section{Yöntem}

Katılımcılar ve işlem. Ölçek 2016-2017 akademik yılında Bursa Uludağ Üniversitesi'nde eğitimine devam eden öğrencilere uygulanmıştır ( $\mathrm{N}=317)$. Örneklemin temsil ediciliğini arttırmak amacıyla kat1lımcıların sayısı her fakültede kayıtlı olan öğrenci sayıları dikkate alınarak belirlenmiștir (İktisadi ve İdari Bilimler Fakültesi [\%20.8], Fen-Edebiyat Fakültesi 
[\%14.2], Mühendislik Fakültesi [\%13.2], Eğitim Fakültesi [\%12.9], Ziraat Fakültesi [\%6.9], Sağlık Bilimleri Fakültesi [\%6], Tıp Fakültesi [\%6], Mimarlık Fakültesi $[\% 5,7]$, İlahiyat Fakültesi [\%5.4], Veterinerlik Fakültesi [\%4.4] ve Spor Bilimleri Fakültesi [\%4.4]). Uygulama belirtilen fakültelerdeki ders saatlerinde gerçekleştirilmiştir. Araştırmanın örneklemi 317 katılımcıdan oluşmaktadır (Kadın: 209; Erkek: 108). Katılımcıların yaş ortalaması $21.3^{\prime}$ tür $(\mathrm{S}=3.06$; yaş aralığ $1=18-54)$. Çalışma için etik onay Bursa Uludağ Üniversitesi Sosyal ve Beşerî Bilimler Etik Kurulu tarafından verilmiştir.

İstatiksel analiz. Ölçeğin faktör yapısını değerlendirmek için iki-adımlı bir işlem uygulanmıştır. İlk olarak örneklemin yaklaşık olarak \%50'sinin rasgele olarak seçildiği dosya bölme komutu kullanılarak veri iki yarıya ayrılmıştır. Barlett ve KMO test sonuçları incelenerek her iki yarı için verinin faktör analizi için uygun olup olmadığına karar verilmiştir. Ölçeğin faktör yapısını değerlendirmek için ilk adımda verinin rasgele olarak seçilen ilk yarısına temel bileșenler metodu ve varimaks eksen döndürmesi uygulanarak açımlayıcı faktör analizi yapılmıştır. Faktör yükü .40 ve üzerinde olup birden çok faktör altında yer alan maddelerde ilgili madde madde havuzundan çıkarılmıştır.

İkinci adımda, ölçeğin faktör yapısını değerlendirmek için doğrulayıcı faktör analizi çerçevesinde uygulanan açımlayıcı faktör analizi (exploratory factor analysis conducted within confirmatory factor analysis framework) uygulanmıştır. Bu analiz yöntemi daha sonra doğrulayıcı faktör analizi ile uyumu araştırılacak modellerin tespit edilmesine yardımcı olmaktadır ve öncül olarak kullanılabileceği belirtilmektedir (Brown, 2006). Doğrulayıc1 faktör analizi çerçevesinde gerçekleştirilen açımlayıcı faktör analizinde faktörlerin regresyon yüklerinin sabitleneceği maddeler (anchor items) ilk adımdaki açımlayıcı faktör analizinde elde edilen faktör yükleri dikkate alınarak tayin edilmektedir (Campbell-Sills, Liverant ve Brown, 2004). Ayrica, bu maddelerin diğer faktörler üzerindeki yüklenmelerini (cross-loading) kisttlayarak ve geri kalan maddelerin serbest olarak tahmin edilmesine izin vererek, ölçeğin veri ile uyumu ve uyumunu artırabilecek değişiklikler tahmin edilmektedir (Campbell-Sills, Liverant ve Brown, 2004). Açımlayıcı ve doğrulayıcı faktör analizinin veri üzerindeki kısıtlamaları benzer olsa da doğrulayıcı faktör analizinde en-çok-olabilirlik (maximum likelihood) yöntemi ile oluşturulan tahmin veri hakkında daha fazla bilgi sağlayarak (faktör yüklerinin anlaml1lık düzeyi ve hata varyanslarının birlikte değişimleri) gerçekçi ve veriye dayalı modellerin geliştirilmesine katk1 sağlamaktadır (Brown, 2006).

Ölçeğin uyumunu tespit etmek için literatürde tavsiye edilen standartlar dikkate alınmıştır. Karşı- laştırmalı uyum indeksi (Comparative Fit Index-CFI) $>0.900$; Tucker-Lewis indeksi (Tucker-Lewis Index - TLI) > 0.900; yaklaşık hataların ortalama karekökü (Root-Mean-Square Error of Approximation-RMSEA) $<0.08$ ve artıkların standart hale getirilmiş ortalama karekökü (Standardized Root Mean Square Residual SRMR) $<0.08$ modelin veri ile kabul edilebilir düzeyde uyumlu olduğuna işaret etmektedir (Brown, 2006). CFI ve TLI değerlerinin .95'e yakın ya da daha yüksek, RMSEA değerinin .06'a yakın ya da daha düşük ve SRMR değerinin .08'e yakın ya da daha düşük olması ise model ile veri arasındaki uyumun iyi olduğu şeklinde kabul edilmektedir (Hu ve Bentler, 1999).

Ölçeğin madde ayırt ediciliğini değerlendirmek amacıyla en düşük ve en yüksek puan alan $\% 27^{\prime}$ lik grupta yer alan katılımcıların her bir maddeye dair ortalama puanları arasındaki fark bağımsız gruplar için $\mathrm{t}$ testi kullanılarak analiz edilmiştir. Ayrıca, ölçeğin yapı geçerliğini değerlendirmek için Tehdit Ölçeği (Stephan, Ybarra ve Bachman, 1999) ile olan ilişsisi incelenmiştir. Bu çalışmada Karaoğlu (2015) tarafindan Tehdit Ölçeğinin Suriyelilere uyarlanmış formatı kullanılmıştır. Beş noktalı Likert tipi ölçekte ("Kesinlikle katılmıyorum" "Katılmıorum", "Kararsızım", "Kat1liyorum", "Kesinlikle katıllyorum") katılımcıların Suriyelilere yönelik gerçekçi ve sembolik düzeydeki tehditlerle ilişkili maddelere katılma düzeylerini belirtmeleri istenmektedir. Ters yönde puanlanan madde bulunmamaktadır. Ölçekten alınan puan arttıkça dış gruba yönelik tehdit algısı artmaktadır (Stephan, Ybarra ve Bachman, 1999; Stephan, Ybarra ve Rios, 2016).

Tüm test puanının ve faktörlerin güvenirliğini test etmek için iç tutarlık güvenirlik katsayısı hesaplanmıştır. Ayrıca madde-toplam korelasyonları ve madde ç1karıldığında elde edilen alfa değerleri rapor edilmiştir. Maddelerin ortalama ve standart sapmaları betimleyici istatistikler kullanılarak rapor edilmiştir. Analizler SPSS (IBM, 2015) ve SPSS Amos (Arbuckle, 2014) programları kullanılarak gerçekleştirilmiştir.

\section{Bulgular}

Açımlayıcı faktör analizi. KMO katsayısı ve Barlett test değeri verinin açımlayıcı faktör analizi için uygun olduğunu göstermiştir (ilk veri seti: KMO $=.945$; Barlett testi istatistiği, $\chi^{2}(165)=2437.23, \mathrm{p}<$ .001 ; ikinci veri seti: $\mathrm{KMO}=.941$; Barlett testi istatistiği, $\left.\chi^{2}(152)=2147.22, p<.001\right)$. Açımlayıcı faktör analizi için rasgele olarak seçilen 165 katılımcının verisi değerlendirilmiş̧ir. Rotasyondan sonra özdeğeri birden büyük olan üç faktör olduğu görülmüştür. Fakat, bir faktörün iki madde dışındaki tüm maddelerinin .40 ve üzerinde faktör yükü ile diğer faktörler altında da 
yer alması nedeniyle iki faktörlü bir çözümün tutumluluk (parsimony) açısından uygun olduğuna karar verilmiştir. Bunun için iki faktör çıkartmak üzere analizler tekrar yürütülmüştür. $\mathrm{Bu}$ işlem sonunda birinci faktör varyansın yaklaşık olarak \%30'unu, ikinci faktör ise varyansın yaklaşık olarak \%26'sını açıklamıştır. Açıklanan toplam varyans \%56.37 olarak bulunmuştur.

Her iki faktör üzerindeki yükü .40 ve üzerinde olan altı madde çıkarılarak tekrar faktör analizi uygulanmıştır $\left(\mathrm{KMO}=.931\right.$; Barlett testi istatistiği, $\chi^{2}(165)$ $=1470.52, \mathrm{p}<.001)$. Bu işlem ile rotasyondan sonra açıklanan toplam varyans $\% 55.85$ olarak hesaplanmıştır. Birinci faktör varyansın yaklaşık olarak \%31'ini, ikinci faktör ise varyansın yaklaşık olarak \%25'ini açıklamaktadır. Faktör yükleri .53 ile .87 arasında değişmektedir ve 6 madde ters yönde puanlanmaktadır. Toplam test puanının iç tutarlılık güvenirlik katsayısı .93 olarak hesaplanmıştır.

Doğrulayıcı Faktör Analizi Çerçevesinde Uygulanan Açımlayıcı Faktör Analizi. Doğrulayıcı faktör analizi çerçevesinde uygulanan açımlayıcı faktör analizi için verinin diğer yarısı kullanılmıştır $(\mathrm{N}=$ 152). Açımlayıcı faktör analizinden elde edilen faktör yükleri dikkate alınarak regresyon yüklerinin sabitlendiği maddeler tayin edildikten sonra modelin uyumunun kabul edilebilir düzeyde olduğu gözlenmiştir (CFI $=.914 ;$ TLI $=.901 ;$ RMSEA $=.077 ;$ SRMR $=.069)$. Maddelerin ilişkili olduğu faktör yükleri .45 ile .81 arasında değişmektedir.

Değişim indisleri incelendiğinde regresyon yükleri tablosunda ikinci faktör ile ilişkilendirilen bir maddenin ("Suriyeli mültecilerin kültürel çeşitlilik açısından bir firsat olduğunu düşünüyorum") ilk faktör altında yer almasının modelin uyumunu arttıracağı tespit edilmiştir. Her iki faktör ile ilişskilendirildiğinde bu maddenin ikinci faktör tarafindan açıklanan faktör yükünün istatistiksel olarak anlamlı olmadığı görülmüştür. Teorik olarak kabul edilebilir olduğu düşünülerek maddenin ilk faktör altında yer almasına karar verilmiştir. $\mathrm{Bu}$ değişiklik modelin uyumunu arttırmıştır (CFI = .936; $\mathrm{TLI}=.926 ; \mathrm{RMSEA}=.067 ; \mathrm{SRMR}=.057)$.

Birlikte değişim (covariance) tablosunda ilk faktör altındaki bir maddenin hata varyansının ("Suriyeli sığınmacıların kamplardaki yaşam standartlarının arttırılmasını gereksiz buluyorum") aynı faktör altında yer alan iki maddenin hata varyansı ile birlikte değişmesine izin verilmesinin modelin uyumunu en fazla arttıracak değişiklik olduğu görülmüştür ("Her ne olursa olsun -savaş hali de dahil olmak üzere- Suriyeli sığınmacılar ülkelerine zorla geri gönderilmelidir" ve "Suriyeli s1ğınmacıların açtığı dükkandan alıșveriș yapabilirim”). Aynı faktör altında yer alan maddelerin hata varyans- larının birlikte değişmesi doğrulayıcı faktör analizinde birkaç şekilde yorumlanmaktadır (Brown, 2006): Hata varyansları arasındaki ilişkinin bir nedeni maddelerin benzer ifadeleri içermesidir. Örneğin benzer kelimeler içeren ya da ters yönde puanlanmış maddelerin hata varyansları birlikte değişebilir. Bir diğer olasılık hata varyansları birlikte değişen maddelere verilen cevapların sosyal kabul edilirlik açısından diğer maddelere kıyasla farklı bir eğilim göstermiş olmalarıdır (Brown, 2006). Ayrıca, hata varyanslarının birlikte değişmesi maddelerin ölçülen faktör dişındaki bir faktörle olan ilişkileri nedeniyle de gözlenebilir (Brown, 2006). Bu çalışmanın açımlayıcı faktör analizi temelinde yürütülmesi nedeniyle hata varyansı diğer maddelerle birlikte değişen maddenin çıkarılmasına karar verilmiştir ("Suriyeli sığınmacıların kamplardaki yaşam standartlarının arttırılmasını gereksiz buluyorum”). Bu maddenin havuzdan çıkarılmasının, hata varyansının diğer maddelerin hata varyansları ile birlikte değişmesine izin verilmesine kıyasla modelin uyumunu arttırdığ görülmüştür. Madde çıkarıldıktan sonra modelin uyumu kabul edilebilir düzeyden iyi düzeye yükselmiştir $(\mathrm{CFI}=.958 ;$ TLI $=.951 ;$ RMSEA $=.055$; $\mathrm{SRMR}=$ .055). Maddelerin ilişkili olduğu faktör yükleri 46 ile .80 arasında değişmektedir ve faktör yükleri $\mathrm{p}<.001$ düzeyinde istatistiksel olarak anlamlıdır. Toplam test puanının Tehdit Ölçeği (Karaoğlu, 2015) ile arasındaki korelasyonun pozitif yönde ve anlamlı olduğu bulunmuştur $(\mathrm{r}(315)=.88, \mathrm{p}<.001)$. Her iki analiz sonucu elde edilen faktör yükleri, varyans yüzdeleri, özdeğerler ve her faktör için hesaplanan iç tutarlılık güvenirlik katsayıları Tablo 2'de gösterilmektedir. Tablo 3'te en düşük ve en yüksek puan alan \%27'lik alt ve üst grup karşılaştırmalarına dair t istatistikleri yer almaktadır. Analiz sonuçları madde ortalamalarının 1.26 ile 4.86 arasında değiştiğini ve tüm maddelerin gruplar arasında $\mathrm{p}<.001$ düzeyinde istatistiksel olarak anlamlı şekilde farklılaştığını göstermiştir.

Güvenirlik. Ölçeğin iç tutarlılık güvenirlik katsayısı .92 olarak hesaplanmıştır $(\mathrm{N}=317)$ ve ölçeğin mükemmel düzeyde güvenirliği olduğuna işaret etmektedir.

Betimsel İstatistikler. İlk faktör için hesaplanan ortalama puan $24.77(\mathrm{~S}=8.39$; puan aralığ $1=9$ - 45) ikinci faktör için 27.61 ( $\mathrm{S}=5.90$; puan aralığ 1 $=9-35)$ olarak bulunmuştur. Ölçekten alınan toplam puanın ortalaması 52.38 ' dir $(\mathrm{S}=12.99$; puan aralığ1 = 22 - 80). Faktörler arasında ortalama puan açısından bir fark olup olmadığı madde sayılarının eşit olmaması nedeniyle hesaplanmamıştır. Bununla birlikte maddelerin orta değerleri ve her madde için en sık tekrar eden cevaplar incelendiğinde katılımcıların cevap stillerinin 
Tablo 2. Açımlayıcı Faktör Analizi $(N=165)$ ve Doğrulayıcı Faktör Analizi Çerçevesinde Uygulanan Açımlayıcı Faktör Analizi $(N=152)$ Sonuçları (Çalışma II)

\begin{tabular}{|c|c|c|c|c|}
\hline \multirow[b]{2}{*}{ Ölçek Maddeleri } & \multicolumn{2}{|c|}{ Faktör 1} & \multicolumn{2}{|c|}{ Faktör2 } \\
\hline & AFT & D/AFA & AFT & $\mathrm{D} / \mathrm{AFA}$ \\
\hline $\begin{array}{l}\text { Her ne olursa olsun (savaş hali de dahil olmak üzere) Suriyeli sı̆̆ınmacılar } \\
\text { ülkelerine zorla geri gönderilmelidir. (Madde 9)* }\end{array}$ & .87 & .74 & .05 & .57 \\
\hline Suriyeli bir sığınmacı ile arkadaş olmak isterim. (Madde 8) ${ }^{R}$ & .79 & .76 & .23 & .58 \\
\hline Suriyelilere yönelik olumsuz tepkileri acımasızca buluyorum. (Madde 22$)^{R}$ & .75 & .75 & .39 & .57 \\
\hline Bir Suriyeli ile komşu olmak beni rahatsız eder. (Madde 14) & .74 & .80 & .25 & .61 \\
\hline $\begin{array}{l}\text { Suriyeli sığınmacıların kamplardaki yaşam standartlarının arttırılmasını } \\
\text { gereksiz buluyorum. (Madde 18) a }\end{array}$ & .73 & - & .23 & - \\
\hline Suriyeli sığınmacılar çalışma hayatına dâhil edilmelidir. (Madde 15) ${ }^{\mathrm{R}}$ & .67 & .66 & .38 & .51 \\
\hline Suriyeli sığınmacılar için yeterli eğitim imkânları sunulmalıdır. (Madde 11) ${ }^{\mathrm{R}}$ & .64 & .64 & .41 & .49 \\
\hline Suriyeliler ile aynı sınıfta eğitim görmekten rahatsız olurum. (Madde 2) & .63 & .71 & .31 & .54 \\
\hline Suriyelilerin açtığı dükkândan alışveriş yapabilirim. (Madde 1$)^{R}$ & .59 & .77 & .43 & .59 \\
\hline $\begin{array}{l}\text { Ülkemizdeki fakirlere harcanması gereken paranın Suriyelilere harcanmasını } \\
\text { doğru bulmuyorum (Madde 5).* }\end{array}$ & .37 & .60 & .70 & .79 \\
\hline $\begin{array}{l}\text { Suriyeli sığınmacı sayısının fazlalığından dolayı sağlık hizmetlerinin aksaması } \\
\text { beni öfkelendirir. (Madde 21) }\end{array}$ & .30 & .59 & .69 & .78 \\
\hline $\begin{array}{l}\text { Suriyeli sığınmacıların yerel halkın iş imkânlarını kısıtladığını düşünüyorum. } \\
\text { (Madde 17) }\end{array}$ & .28 & .52 & .69 & .68 \\
\hline $\begin{array}{l}\text { Suriyeli sı̆̆ınmacıların kültürel çeşitlilik açısından bir firsat olduğunu } \\
\text { düşünüyorum. (Madde } 4)^{\mathrm{R}}\end{array}$ & .35 & .66 & .65 & .50 \\
\hline Suriyeli sığınmacılar T.C vatandaşlığına alınmamalıdır. (Madde 15) & .32 & .42 & .63 & .55 \\
\hline $\begin{array}{l}\text { Türk işveren ve iş̧̧iler vergi verirken Suriyeli işveren ve işçilerin vergi } \\
\text { vermemesi yanlış bir uygulamadır. (Madde 12) }\end{array}$ & .17 & .37 & .63 & .48 \\
\hline $\begin{array}{l}\text { Suriyeli sı̆̆ınmacıların fazlalığından dolayı verilen hizmetler aksamaktadır. } \\
\text { (Madde 6) }\end{array}$ & .35 & .55 & .58 & .72 \\
\hline $\begin{array}{l}\text { Suriyeli sığınmacılar ülkemizde misafir olduklarının farkında olmalı ve buna } \\
\text { göre davranmalılar. (Madde 3) }\end{array}$ & .14 & .35 & .53 & .46 \\
\hline Özdeğerler & 5.30 & & 4.19 & \\
\hline Varyans yüzdeleri & 31.19 & & 24.66 & \\
\hline Cronbach alfa katsayısı & 0.91 & 0.91 & 0.85 & 0.83 \\
\hline
\end{tabular}

Not. Maddeler ilişkili oldukları faktörler altında kalın yazı tipiyle gösterilmiştir. ${ }^{\mathrm{R} T e r s ~ y o ̈ n d e ~ p u a n l a n a n ~ m a d d e . ~}{ }^{\mathrm{a} c ̧ ı k a r ı l a n ~ m a d d e . ~ * r e g r e s y o n ~ y u ̈ k u ̈ ~ s a b i t l e n e n ~}$ madde. AFT = Açımlayıcı faktör analizi. D/AFA = Doğrulayıcı faktör analizi çerçevesinde uygulanan açımlayıcı faktör analizi.

faktörler arasında farklılaștığı görülmüştür. Katılımc1lar ilk faktör ile ilişkili maddelere "kesinlikle katılmıyorum" "katılmıyorum", ikinci faktör ile ilişkili maddelere "katılıyorum" "kesinlikle katılıyorum" şeklinde cevap verme eğilimi göstermişlerdir. Her iki çalışmadaki maddelere dair betimsel istatistikler, madde-toplam korelasyonları ve madde çıkarıldı ğında elde edilen alfa değerleri Tablo 4'te gösterilmektedir. 
Tablo 3. En Düşük ve En Yüksek Puan Alan \%27’lik Alt Grup ve Üst Grup Karşılaştırmalarına Dair t İstatistikleri

\begin{tabular}{|c|c|c|c|c|c|c|c|c|c|}
\hline \multirow{2}{*}{$\begin{array}{c}\text { Ölçek } \\
\text { maddeleri }\end{array}$} & \multicolumn{3}{|c|}{ Alt Grup } & \multicolumn{3}{|c|}{ Üst Grup } & \multirow{2}{*}{$\begin{array}{c}\text { Ortalama farkın } \\
\% 95 \text { GA }\end{array}$} & \multirow[b]{2}{*}{$\mathrm{t}$} & \multirow[b]{2}{*}{ df } \\
\hline & Ort & S & $\mathrm{N}$ & Ort & S & $\mathrm{N}$ & & & \\
\hline \multicolumn{10}{|l|}{ Faktör 1} \\
\hline Madde 9 & 1.26 & .71 & 86 & 3.45 & 1.18 & 86 & $-2.49,-1.90$ & $-14.78 * * *$ & 138,61 \\
\hline Madde $8^{R}$ & 1.86 & .91 & 86 & 3.95 & 1 & 86 & $-2.38,-1.80$ & $-14.32 * * *$ & 168,34 \\
\hline Madde $22^{\mathrm{R}}$ & 1.66 & .86 & 86 & 3.93 & .9 & 86 & $-2.53,-2$ & $-16,82 * * *$ & 170 \\
\hline Madde 14 & 1.72 & .76 & 86 & 4.09 & 1 & 86 & $-2.64,-2,1$ & $-17.49 * * *$ & 158.62 \\
\hline Madde $15^{\mathrm{R}}$ & 1.85 & .82 & 86 & 3.88 & 1.1 & 86 & $-2.33,-1.74$ & $-13.77 * * *$ & 157.1 \\
\hline Madde $11^{\mathrm{R}}$ & 1.85 & 1.05 & 86 & 3.74 & 1.14 & 86 & $-2.23,-1.56$ & $-11.31 * * *$ & 169.06 \\
\hline Madde 2 & 1.29 & .61 & 86 & 3.48 & 1.24 & 86 & $-2.48,-1.9$ & $-14.63 * * *$ & 123.78 \\
\hline Madde $1^{\mathrm{R}}$ & 1.77 & .85 & 86 & 4.26 & 1.14 & 86 & $-2.8,-2.19$ & $-16.23 * * *$ & 157.19 \\
\hline Madde $4^{\mathrm{Ra}}$ & 2.44 & 1.01 & 86 & 4.47 & .91 & 86 & $-2.31,-1.73$ & $-13.73 * * *$ & 170 \\
\hline \multicolumn{10}{|l|}{ Faktör 2} \\
\hline Madde 5 & 2.28 & 1.11 & 86 & 4.77 & .71 & 86 & $-2.78,-2.21$ & $-17.45^{* * *}$ & 144,84 \\
\hline Madde 21 & 2.4 & 1.25 & 86 & 4.62 & .67 & 86 & $-2.52,-1.92$ & $-14.52 * * *$ & 130.38 \\
\hline Madde 17 & 2.76 & 1.17 & 86 & 4.8 & .66 & 86 & $-2.33,-1.77$ & $-14.12 * * *$ & 134.95 \\
\hline Madde 10 & 3.13 & 1.24 & 86 & 4.86 & .63 & 86 & $-2.03,-1.43$ & $-11.5^{* * *}$ & 126.52 \\
\hline Madde 12 & 3.84 & 1.04 & 86 & 4.86 & .63 & 86 & $-1.28,-.76$ & $-7.8 * * *$ & 140.8 \\
\hline Madde $6^{\mathrm{a}}$ & 2.47 & 1.01 & 86 & 3.88 & .76 & 86 & $-2.37,-1.83$ & $-15.4 * * *$ & 157.58 \\
\hline Madde 3 & 3.24 & 1.35 & 86 & 4.62 & 1.1 & 86 & $-1.74,-1$ & $-7.3 * * *$ & 163 \\
\hline
\end{tabular}

Not. $\mathrm{GA}=$ Güven Aralığ $1,{ }^{\mathrm{R}}$ Ters yönde puanlanan madde. ${ }^{\mathrm{a}}$ eklenen madde. Ort $=$ ortalama. $\mathrm{S}=$ standart sapma.

$* * * p<.001$

\section{Genel Tartışma}

Bu çalışmada "Suriyelilere Yönelik Tutumlar Ölçeği”"nin psikometrik özellikleri iki ayrı çalışmada incelenmiştir. İlk çalışmada açımlayıcı faktör analizi ile ölçeğin üç faktörlü olarak toplam varyansın \%55'ini açıkladığ1 görülmüştür. İkinci çalışmada yeni maddeler eklenmiş ve ölçeğin geçerliği iki aşamalı olarak verinin rastgele bölünen iki yarısı üzerinde araştırılmıştır. Rastgele olarak seçilen ilk yarıda açımlayıcı faktör analizi ile ölçeğin ilk çalışmadaki üç faktörlü yapısı iki faktöre indirgenmiştir. İkinci aşamada doğrulayıcı faktör analizi çerçevesine gerçekleştirilen açımlayıcı faktör analizi ile ölçeğin iki faktörlü yapısının veri ile kabul edilebilir 
Tablo 4. "Suriyelilere Yönelik Tutumlar Ölçeği”nin Madde Puan Ortalamaları, Standart Sapmaları, Ortanca ve Tepe Değerleri (Çalışma I ve Çalışma II) ile Madde-Toplam Korelasyonları ve Madde Çıkarıldığında Alfa Değerleri (Çalışma II)

\begin{tabular}{|c|c|c|c|c|c|c|c|c|}
\hline \multirow{2}{*}{$\begin{array}{c}\text { Ölçek } \\
\text { maddeleri }\end{array}$} & \multicolumn{3}{|c|}{ Çalışma I $(\mathrm{N}=184)$} & \multicolumn{3}{|c|}{ Çalışma II (N = 317) } & \multicolumn{2}{|c|}{ Çalışma II $(\mathrm{N}=317)$} \\
\hline & Ort (S) & Ortanca & $\begin{array}{l}\text { Tepe } \\
\text { Değeri }\end{array}$ & Ort (S) & Ortanca & $\begin{array}{c}\text { Tepe } \\
\text { Değeri }\end{array}$ & $\begin{array}{l}\text { Madde-Toplam } \\
\text { Korelasyonu }\end{array}$ & $\begin{array}{c}\text { Madde } \\
\text { Çıkarıldığında } \alpha\end{array}$ \\
\hline \multicolumn{9}{|l|}{ Faktör 1} \\
\hline Madde (9) & $1.91(1.14)$ & 2 & 1 & $2.22(1.26)$ & 2 & 1 & .66 & .91 \\
\hline Madde $(8)^{\mathrm{R}}$ & $2.34(1.10)$ & 2 & 2 & $2.78(1.17)$ & 3 & 3 & .68 & .91 \\
\hline Madde $(22)^{\mathrm{R}}$ & $2.29(1.19)$ & 2 & 2 & $2.71(1.21)$ & 3 & 3 & .73 & .91 \\
\hline Madde (14) & $2.27(1.18)$ & 2 & 1 & $2.77(1.24)$ & 3 & 2 & .71 & .91 \\
\hline Madde $(15)^{\mathrm{R}}$ & $2.46(1.18)$ & 2 & 2 & $2.82(1.21)$ & 3 & 2 & .66 & .91 \\
\hline Madde $(11)^{\mathrm{R}}$ & $2.15(1.10)$ & 2 & 2 & $2.66(1.22)$ & 2 & 2 & .62 & .91 \\
\hline Madde (2) & $1.98(1.21)$ & 2 & 1 & $2.33(1.27)$ & 2 & 2 & .63 & .91 \\
\hline $\operatorname{Madde}(1)^{\mathrm{R}}$ & $2.33(1.17)$ & 2 & 2 & $3.09(1.38)$ & 3 & 2 & .70 & .91 \\
\hline Madde (4) R a & - & - & - & $3.55(1.24)$ & 4 & 4 & .62 & .91 \\
\hline \multicolumn{9}{|l|}{ Faktör 2} \\
\hline Madde (5) & $3.21(1.34)$ & 3 & 3 & $3.73(1.35)$ & 4 & 5 & .68 & .91 \\
\hline Madde (21) & $3.17(1.34)$ & 3 & 4 & $3.66(1.27)$ & 4 & 4 & .66 & .91 \\
\hline Madde (17) & $3.48(1.28)$ & 4 & 4 & $3.91(1.21)$ & 5 & 5 & .62 & .91 \\
\hline Madde (10) & $3.49(1.31)$ & 4 & 5 & $4.15(1.20)$ & 5 & 5 & .54 & .92 \\
\hline Madde (12) & $4.13(1.13)$ & 4 & 5 & $4.49(0.87)$ & 5 & 5 & .38 & .92 \\
\hline Madde (6) & - & - & - & $3.59(1.21)$ & 4 & 5 & .59 & .92 \\
\hline Madde (3) & $3.73(1.30)$ & 4 & 5 & $4.07(1.25)$ & 5 & 5 & .39 & .92 \\
\hline
\end{tabular}

Not. Ölçek maddelerinin yanında parantez içinde bulunan sayılar madde numaralarını göstermektedir. ${ }^{\mathrm{R}}$ Ters yönde puanlanan madde. ${ }^{\mathrm{a}}$ eklenen madde. Ort = ortalama. $\mathrm{S}=$ standart sapma.

düzeyde uyumlu olduğu bulunmuştur. Değişim indisleri doğrultusunda ikinci faktör altında yer alan bir maddenin ilk faktör altında yer alması ve ilk faktörle ilişkilendirilen bir maddenin çıkarılması ölçeğin uyumunu iyi düzeye yükseltmiştir. Maddelerin ilişkili oldukları faktör üzerindeki yükleri istatistiksel olarak anlamlı ve yeterli düzeydedir. Madde toplam korelasyon değerleri ve \%27'lik alt grup ve üst grup karşılaştırmalarında madde puan ortalamalarının gruplar arasında istatistiksel olarak anlamlı şekilde farklı olması madde ayırt ediciliği ve ölçeğin geçerliği için kanıt sağlamaktadır. "Tehdit Ölçeği” (Karaoğlu, 2015) ile "Suriyelilere Yönelik Turumlar Ölçeğì" arasındaki olumlu yöndeki ilişki her iki ölçeğin benzer yapıları ölçtügüüne işaret etmektedir. İç tutarlılık 
güvenirlik katsayısı (.92) ölçeğin mükemmel düzeyde güvenirliği olduğunu göstermiştir. Bu bulgular doğrultusunda "Suriyelilere Yönelik Tutumlar Ölçeği”"nin yeterli psikometrik özelliklere sahip güvenilir ve geçerli bir ölçüm aracı olduğu söylenebilir.

Ölçeğin birinci faktörü çalışmanın ilk kısmında gözlenen ve gruplar arası kaygı ve sosyal baskınlık eğilimi ile ilişkili bulunan maddelerin tümünü içermektedir. Davranış düzeyinde sosyal mesafe ve ayrımcılığa dayalı tutumlar ile ilişkili olması nedeniyle bu faktörün ilk çalışmadaki gibi "ayrımcıllk" olarak tanımlanmasına karar verilmiștir. İkinci faktör, Suriyelilerin kaynaklardan faydalanması ve Türkiye'deki statüleri ile ilişkili maddelerden oluşmaktadır. İlk çalışmanın gerçekçi tehditler ile ilişkilendirilen iki faktörünün ikinci çalışmada tek bir faktöre indirilebileceği görülmüştür. Bu faktör "grup ve birey düzeyinde gerçekçi tehditler" olarak tanımlanmıştır (Stephan, Renfro ve Davis, 2008). "İstihdamın ve maddi kaynakların dağılımı", "vatandaşlık hakkı", "misafir statüsü" ve "vergi muafiyeti”" ile ilişsili maddelerde deneyimlenen tehdit algısının grup düzeyinde gerçekleştiği düşünülmektedir (örneğin, "Ülkemizdeki fakirlere harcanması gereken paranın Suriyelilere harcanmasını doğru bulmuyorum"). Sağlı hizmetlerinin aksaması konusunda yaşanan olumsuz duygularla ilişkili madde ise tehdit algısının bireysel düzeydeki sonuçları ile ilişkilidir ("Suriyeli sığınmacı sayısının fazlalığından dolayı sağlık hizmetlerinin aksaması beni öfkelendirir").

Gerçekçi tehditlerin göçmenlere yönelik olumsuz tutumlarla ilişkili olduğu daha önce gösterilmiştir (Pereira, Vala ve Costa-Lopes, 2010). Deneyimlenen önyarg1nın diş grubun iç gruba gerçek anlamda yönelttiği tehditlerden çok iç grubun algıladığı tehditlerle ilişkili olduğu düşünülmektedir (Stephan, Ybarra ve Rios, 2016). Örneğin Almanya'da gö̧çmenlere yönelik algılanan tehdit düzeyinin araştırıldığı bir çalışmada katılımcıların algıladıkları tehdit miktarının yaşadıkları bölgedeki gerçek göçmen sayısından çok algıladıkları göçmen sayısı ile ilişkili olduğu bulunmuştur (Semyonov, Raijman, Tov ve Schmidt, 2004). Çalışmalar gerçek anlamda var olan tehdit faktörlerinin sıklikla günah keçisi olarak seçilen dış grup üyelerine yansıtıldığına işaret etmektedir (Riek, Mania ve Gaertner, 2006). Ayrica, medyada ve politik söylemde dış grubun ele alınış şekli iç grubun tutumlarını etkilemektedir (Dijk, 2008). Bu çalışmanın bulguları Suriyelilere yönelik önyargı ve ayrımcilığın azaltılmasında algılanan gerçekçi tehditler konusunda çalışılmasının uyum ve bütünleșmeye katkı sağlayacağını göstermektedir.

İlk çalışmada "birey düzeyinde gerçekçi tehditler" faktörü ile ilişkilendirilen bazı maddeler ikinci çalışmada yer almamıştır. Bu maddelerin içeriği güvenlik ve birlikte yaşama konusunda algılanan gerçekçi tehditlerle ilişkilidir. Yöntemsel açıdan .40 ve üzerinde faktör yükü olup tek bir faktör altında yer alan maddelerin madde havuzunda tutulması ve tutumluluk açısından iki faktörlü bir çözümün tercih edilmesi bu maddelerin herhangi bir faktör altında yer almaması ile sonuçlanmış olabilir. Diğer bir olasılık tutumların dinamik yapısının sonuçları etkilemiş olabileceğidir (Jones ve Dovidio, 2018). İlk çalş̧mada bütünlüğe ve iyi oluşa yönelik birey düzeyinde gerçekçi tehditler ile ilişkilendirilen güvenlik ve birlikte yaşama ile ilgili madde içerikleri çalışmanın ikinci aşamasında tutumların belirlenmesinde belirgin bir rol oynamamıs olabilir.

Katılımcıların her iki çalışmadaki ayrımcılık faktörü ile ilişkili tutumlarının gerçekçi tehditler faktörü ile ilişkili tutumlarının aksine daha olumlu olduğu gözlenmiştir. Ayrımcılık faktörü gruplar arası kaygı ve sosyal baskınlık eğilimi ile ilişkili maddelerden oluşmaktadır. Öz-bildirim düzeyinde "ayrımcılık" faktörü açısından gözlenen olumlu tutumun, "grup ve birey düzeyinde gerçekçi tehditler" faktörü açısından gözlenmemiş olması Suriyelilere yönelik tutumun genel olarak olumlu olduğu yönündeki bir çıkarımın yapılmasını engellemektedir. Katılımcılar öz-bildirim düzeyinde toplumsal kodların açık olduğu koşulda ayrımcılık yapmadıklarını belirtmelerine rağmen ("ayrımcılık" faktörü), toplumsal kodların açık olmadığı koşulda ("grup ve birey düzeyinde gerçekçi tehditler" faktörü) iç grubu kayıracak şekilde tutum sergilemişlerdir. Bu doğrultuda, katılımcıların Suriyelilere yönelik tutumunun örtük olarak deneyimlenen ayrımcılık ile ilişkisinin daha sonra araştııılması gerektiği düşünülmektedir (Dovidio, Gaertner ve Pearson, 2016).

Örtük ayrımcılık sosyal, kültürel ve politik koşullar ile yakından ilişkilidir. Örneğin, Forman (2004) Amerika'daki zencilere yönelik örtük ayrımcılığı renk körlüğü (color-blindness) ile açıklamaktadır. Amerika'da sivil haklar hareketi sonrası eşitliğin Amerikan ideali olarak yasal ve kişiler arası ilişkileri belirlemesi, Amerikalıların ırk ve etnik köken açısından kendilerini renk körü olarak tanımlamaları ile sonuçlanmıştır. Forman'a (2004) göre renk körlüğü Amerikalıların ırka dayalı deneyimledikleri ayrımcılığı ortadan kaldırmamıştır. Aksine, ideal olarak kabul edilen renk körlüğü ile gerçekte deneyimlenen olumsuz tutum arasındaki tutarsızlık ayrımcıllı̆ın örtük olarak ifade edilmesi ile sonuçlanmıştır (Forman, 2004). Yani, Amerika'daki zencilere yönelik örtük ayrımcılı̆̆ın uzun zamandan beri süregelen ve otomatik olarak gerçekleşen ırka dayalı ayrımcılık ile ilişkili sosyo-politik bir süreç tarafından belirlendiği söylenebilir. Türkiye'deki Suriyelilere yönelik tutumların ise Suriye'deki iç-savaşın başladığı ve Suriyelilerin Türkiye sınırını geçerek ülkeye geldiği ilk y1llarda olumlu iken zaman içinde olumsuz yöne doğru kaydığı bir süreç söz konusudur (Yıldız Nielsen, 2016). Ayrıca Amerika'daki zencilere 
yönelik ayrımcılığın aksine Türkiye'deki Suriyelilere yönelik örtük ayrımcılığın ırk temelinde değil ("Arap") "Suriyeli" olarak tanımlanan öteki temelinde gerçekleştiği düşünülmektedir. Sonuç olarak, Suriyelilere yönelik tutumun örtük ayrımcılık ile ne düzeyde ilişkili olduğunun sonraki çalışmalarda değerlendirilmesi gerekmektedir. Suriyelilerin ötekileştirilmesine yönelik sosyal, kültürel ve politik koşulların araştırılması bütünleşme konusundaki müdahalelerin geliştirilmesine katkı sağlayabilir.

"Suriyeli sığınmacıların kültürel çeşitlilik açısından bir firsat olduğunu düşünüyorum" maddesinin gerçekçi tehditler faktörüne kıyasla ayrımcılık faktörü altında yer alması ölçeğin uyumunu arttırmaktadır. Ayrıca katılımcılar genel olarak Suriyelilerin kültürel çeşitliliğini bir firsat olarak değerlendirmediklerini belirtmişlerdir. $\mathrm{Bu}$ maddeye yönelik tutumların Suriyelilerin kültürlenme sürecine dair ideolojik beklentiler (çok kültürlülük ya da asimilasyon) ile ilişkili olabileceği düşünülmektedir. Avrupa'da yapılan çalışmalarda, göçmenlerin kendi grup kimliklerini ve kültürlerini terk ederek asimile olmalar1 ve geldikleri kültüre uyum sağlamaları gerektiği yönündeki beklentinin olumsuz tutumlarla ilişkili olduğu, çok kültürlülük yönündeki beklentinin ise gruplar aras1 etkileşimi olumlu yönde etkilediği rapor edilmektedir (Verkuyten, 2006). Ayrıca, çok kültürlülüğe dair olumlu tutum dış grubun farklılıklarının fark edilmesini ve faydalı olarak değerlendirilmesini gerektirmektedir (Kauff ve Wagner, 2012). Suriyelilerin kültürel çeşitliliğinin bir firsat olarak değerlendirilmemiş olması gruplar arasındaki kültürler arası farkl1lıkların görmezden gelinmesi ile ilgili olabilir. Ayrıca, dış grubun farklılıklarının görmezden gelinmesi ve iç grup ile benzerliklerine vurgu yapılması örtük olarak deneyimlenen asimilasyon yönündeki beklentiler ile ilişkilidir (Dovidio, Gaertner ve Pearson, 2016). Benzerliklere vurgu yapmak hem bireyin görünürde eşitlikçi değerleri ile uyumludur hem de örtük olarak deneyimlediği ve iç grubun mevcut üstünlüğünü korumaya yönelik tutumu ile çatışmamaktadır (Dovidio, Gaertner ve Pearson, 2016). Suriyelilerin kültürel açıdan gözlenen farklılıklarının bir firsat olarak değerlendirilmemiş olması farklılıklardan çok benzerliklerin önemsenmesi ile sonuçlanan ve gerçekte Suriyeli kimliğinin asimile olması gerektiği yönündeki örtük beklenti ile ilişkili olabilir. Dolayısıyla bu maddenin ayrımcılık faktörü altında yer almasının teorik olarak kabul edilebilir olduğu düşünülmektedir.

Çalışmanın bulgularının kısıtlılıkları dikkate alınarak değerlendirilmesi gerekmektedir. Örneğin katılımcıların Suriyeli bir tanıdığının olması ya da etnik/ulusal kimlikleri ile özdeşleşme düzeyleri tutumlarını etkilemiş olabilir. Ölçeğin üniversite öğrencilerinde gözlenen faktör yapısının farklı alt-gruplar için homojen olup olmadığına ve ölçüm sabitliğine (measurement invariance) dair bilgi edinilmesi gerekmektedir. Çalışmada büyük bir örnekleme erişilmiş ve örneklemin temsil ediciliğini artırmak amacıyla her fakültedeki öğrenci sayıları dikkate alınarak uygulama yapılmıştır. Bununla birlikte, daha geniş bir örnekleme erişilerek ölçeğin üniversite örneklemindeki faktör yapısının doğrulayıcı faktör analizi ile sınanması bir sonraki rasyonel adım olmalıdır. Ölçeğin madde içerikleri bireysel düzeyde tutumları değerlendirmek üzere geliştirilen maddelerden oluştuğu için iç grup aidiyetinden çok dış grubun belirginliği ön plandadır. Daha sonraki çalışmalarda sosyal baskınlık eğilimi ölçeği ile ilişkisinin incelenmesi ölçeğin yapı geçerliği için ek kanıt sağlayabilir. Ölçek maddelerinin olumlu ve olumsuz yöndeki tutum ifadeleri açısından denk olmamasının çalışma bulguları üzerinde karıştırıcı bir etkisi olabilir. Son olarak, ölçeğin Türkiye'deki Suriyelilere yönelik tutumları ölçmek üzere geliştirilmiş olması güçlü yönlerinden biri olmakla birlikte uygulama açısından bir sınırlılık olarak düşünülebilir.

$\mathrm{Bu}$ çalışmada büyük bir ildeki üniversite öğrencilerinin Suriyelilere yönelik tutumları değerlendirilmiştir. Çalışmanın bulguları gruplar arası, bireysel ve ideolojik düzeydeki beklentilerin üniversite öğrencilerinin Suriyelilere yönelik bireysel tutumlarını belirlemiş olabileceğine işaret etmektedir. Daha önceki çalışmalarda büyük kentlerde yaşayan ve eğitim düzeyi yüksek olan bireylerin daha az önyargılı tutum sergiledikleri rapor edilmiştir (Brenner ve Fertig, 2006; Card, Dustmann ve Preston, 2005). Bu çalışmada bir karşılaştırma grubu olmaması nedeniyle böyle bir çıkarım yapmak mümkün olmamıştır. Fakat genç ve üniversite eğitimine devam eden öğrencilerin eşitliğe dayalı değerlere yaptıkları vurgunun örtük ayrımcılık ile ne düzeyde ilişkili olduğunun sonraki çalışmalarda değerlendirilmesi gerektiği düşünülmektedir. Ayrımcılığın örtük ölçüm araçları kullanılarak davranışsal düzeyde değerlendirildiği çalışmalar bu konudaki bilgi düzeyini arttırabilir (Dovidio, Gaertner ve Pearson, 2016). Güvenilir ve geçerli olduğu gösterilen "Suriyelilere Yönelik Tutumlar Ölçeği”" Suriyelilere yönelik önyargı ve ayrımcılığın ölçülmesi konusunda daha sonraki çalışmalarda kullanılabilir. 


\section{Kaynaklar}

Aral, T., Sevi, B., \& Aydinli-Karakulak, A. (2016, Kasım). Göçmen ve mültecilere karşı tutumların yordayıcıları: İgrenme hassasiyeti ve gruplar arası kaygı [Öz]. 1. Sosyal Psikoloji Kongresinde sunulan bildiri, Başkent Üniversitesi, Ankara.

Arbuckle, J. L. (2014). Amos (Sürüm 23.0) [Bilgisayar Program1]. Chicago: IBM SPSS.

Bartlett, M. S. (1950). Tests of significance in factor analysis. British Journal of Statistical Psychology, 3(2), 77-85.

Birleşmiş Milletler (2006, Haziran). UNHCR Master Glossary of Terms. http://www.refworld.org/doci$\mathrm{d} / 42$ ce $7 \mathrm{~d} 444$.html

Birleşmiş Milletler Mülteciler Yüksek Komiserliği (2018, Temmuz). Operational Portal. https:// data2.unhcr.org/en/situations/syria

Brenner, J., \& Fertig, M. (2006). Identifying the determinants of attitudes towards immigrants: A structural cross-country analysis (Rapor no. DP 2306). Bonn: Institute for the Study of Labor.

Brown, T. A. (2006). Confirmatory factor analysis for applied research. New York: Guilford Press.

Campbell-Sills, L., Liverant, G. I., \& Brown, T. A. (2004). Psychometric Evaluation of the Behavioral Inhibition/Behavioral Activation Scales in a Large Sample of Outpatients With Anxiety and Mood Disorders. Psychological Assessment, 16(3), 244254.

Card, D., Dustmann, C., \& Preston, I. (2005). Understanding attitudes to immigration: The migration and minority module of the first European Social Survey (Rapor no. CDP 03/05). Londra: Centre for Research and Analysis of Migration, Department of Economics, University College London.

Dijk, T. A. (2008). Discourse and racism. T. A. Dijk (Ed.), Discourse and power içinde (s. 102-119). New York: Palgrave Macmillan.

Dovidio, J. F., \& Gaertner, S. L. (2004). Aversive racism. M. P. Zanna (Dizi Ed.), Advances in Experimental Social Psychology içinde (Cilt 36, s. 1-51). San Diego: Elsevier Academic.

Dovidio, J. F., Gaertner, S. L., Nier, J. A., \& Hodson, G. (2005). Contemporary racial bias: When good people do bad things. A. G. Miller (Ed.), The social psychology of good and evil (1. bask1) içinde (s. 141-167). New York: Guilford Press.

Dovidio, J. F., Gaertner, S. L., \& Pearson, A. R. (2016). Racism among the well intentioned: Bias without awareness. A. G. Miller (Ed.), The social psychology of good and evil (2. bask1) içinde (s. 95-118). New York: Guilford Press.
Ekmekci, P. E. (2017). Syrian refugees, health and migration legislation in Turkey. Journal of Immigrant and Minority Health, 19(6), 1434-1441.

Erdoğan, M. (2014). Türkiye'deki Suriyeliler: Toplumsal kabul ve uyum. Ankara: Hacettepe Üniversitesi Göç ve Siyaset Araştırma Merkezi.

Finney, N., \& Peach, E. (2004). Attitudes toward Asylum Seekers, Refugees and Other Immigrants: A literature review for the Commission for Racial Equality. Londra: Information Centre about Asylum and Refugees in the UK, King's College London.

Forman, T. A. (2004). Color-blind racism and racial indifference: The role of racial apathy in facilitating enduring inequalities. A. E. Lewis ve M. Krysan (Ed.), The changing terrain of race and ethnicity (s. 43-66) içinde. New York: Russell Sage Foundation.

Hindriks, P., Verkuyten, M., \& Coenders, M. (2014). Dimensions of social dominance orientation: The roles of legitimizing myths and national identification. European Journal of Personality, 28(6), 538549.

Hinnebusch, R. (2019). What went wrong: Understanding the trajectory of Syria's conflict. L. Matar ve A Kadri (Ed.), Syria: From National Independence to Proxy War (pp. 29-52) içinde. Cham: Palgrave Macmillan.

Hodson, G., Hooper, H., Dovidio, J. F., \& Gaertner, S. L. (2005). Aversive racism in Britain: The use of inadmissible evidence in legal decisions. European Journal of Social Psychology, 35(4), 437-448.

Hu, L., \& Bentler, P. M. (1999). Cutoff criteria for fit indexes in covariance structure analysis: Conventional criteria versus new alternatives. Structural Equation Modeling: A Multidisciplinary Journal, $6(1), 1-55$.

Goldewijk, B. K. (2017). International mediation in Syria's complex war: Strategic implications. P. A. E. Ducheine ve F. P. B. Osinga (Ed.), Netherlands Annual Review of Military Studies 2017 (pp. 107-123) içinde. The Hauge: TMC Asser Press.

Göker, G., \& Keskin, S. (2015). Haber medyası ve mülteciler: Suriyeli mültecilerin Türk yazılı basınındaki temsili. Iletişim Kuram ve Araştırma Dergisi, 41, 229-256.

IBM Corp. (2015). IBM SPSS Statistics for Windows, Sürüm 23.0. Armonk: IBM Corp.

International Crisis Group. (2016). Turkey's refugee crisis: The politics of permanence. (Rapor no. Europe Report no 241). Brüksel: Yazar.

Jones, J. M., \& Dovidio, J. F. (2018). Change, challenge, and prospects for a diversity paradigm in social psychology. Social Issues and Policy Review, 12(1), 7-56. 
Kaiser, H. F., \& Rice, J. (1974). Little Jiffy, Mark Iv. Educational and Psychological Measurement, 34(1), 111-117.

Karaoğlu, E. (2015). The role of social dominance orientation, empathy and perceived threat in predicting prejudice of Turkish citizens toward Syrian immigrants. Yayımlanmamış yüksek lisans tezi. Orta Doğu Teknik Üniversitesi, Ankara.

Kauff, M., \& Wagner, U. (2012). Valuable therefore not threatening: The influence of diversity beliefs on discrimination against immigrants. Social Psychological and Personality Science, 3(6), 714-721.

Keleş, S. Ç., Aral, T., Yıldırım, M., Kurtoğlu, E., \& Sunata, U. (2016). Attitudes of Turkish youth toward Syrian refugees in respect to youths' gender, income, education, and city: A Scale development study. D. Eroglu, J. H. Cohen ve I. Sirkeci (Ed.), Turkish migration 2016: Selected papers (s. 155$163)$ içinde. Londra: Transnational Press.

Kılcan, B., Çepni, O., \& Kılınç, A. Ç. (2017). Mülteci öğrencilere yönelik tutum ölçeğinin geliștirilmesi. Journal of Human Sciences, 14(2), 1045-1057.

Köksal, Ç., Köksal, T., \& Köksal, M. (2017). Suriyelilere yönelik bakış açısı ölçeği geliştirme çalışması. Uluslararası Sosyal Araştırmalar Dergisi, 10(51), 538-550.

Lawshe, C.H. (1975). A quantitative approach to content validity. Personnel Psychology, 28, 563-575.

Murray, K. E., \& Marx, D. M. (2013). Attitudes toward unauthorized immigrants, authorized immigrants, and refugees. Cultural Diversity \& Ethnic Minority Psychology, 19(3), 332-341.

Orhan, O., \& Senyücel Gündoğan, S. (2015). Suriyeli sığınmacıların Türkiye'ye etkileri (Rapor no. 195). Ankara: Orta Doğu Stratejik Araştırmalar Merkezi ve Türkiye Ekonomik ve Sosyal Etüdler Vakfi.

Pandır, M., Efe, İ., Paksoy, A. F. (2015). Türk basınında Suriyeli temsili üzerine bir içerik analizi. Marmara Iletişim Dergisi, 24, 1-26.

Park, B., \& Rothbart, M. (1982). Perception of out-group homogeneity and levels of social categorization: Memory for the subordinate attributes of in-group and out-group members. Journal of Personality and Social Psychology, 42(6), 1051-1068.

Pearson, A. R., Dovidio, J. F., \& Gaertner, S. L. (2009). The nature of contemporary prejudice: Insights from aversive racism. Social and Personality PSychology Compass, 3(3), 314-338.

Pereira, C., Vala, J., \& Costa-Lopes, R. (2010). From prejudice to discrimination: The legitimizing role of perceived threat in discrimination against immigrants. European Journal of Social Psychology, 40(7), 1231-1250.
Pettigrew, T. F., \& Meertens, R. W. (1995). Subtle and blatant prejudice in Western Europe. European Journal of Social Psychology, 25(1), 57-75.

Reicher, S. D. (2004). The context of social psychology: Domination, resistance and change. Political Psychology, 25, 40-62.

Riek, B. M., Mania, E. W., \& Gaertner, S. L. (2006). Intergroup threat and outgroup attitudes: A meta-analytic review. Personality and Social Psychology Review, 10(4), 336-353.

Schweitzer, R., Perkoulidis, S., Krome, S., Ludlow, C., \& Ryan, M. (2005). Attitudes towards refugees: The dark side of prejudice in Australia. Australian Journal of Psychology, 57(3), 170-179.

Semyonov, M., Raijman, R., Tov, A. Y., \& Schmidt, P. (2004). Population size, perceived threat, and exclusion: A multiple-indicators analysis of attitudes toward foreigners in Germany. Social Science Research, 33(4), 681-701.

Sidanius, J., \& Pratto, F. (2004). Social dominance theory: A new synthesis. J. T. Jost ve J. Sidanius (Ed.), Political psychology: Key readings içinde (s. 420442). New York: Psychology Press.

Stephan, W. G. (2014). Intergroup anxiety: Theory, research, and practice. Personality and Social Psychology Review, 18(3), 239-255.

Stephan, W. G., Renfro, C. L., \& Davis, M. D. (2008). The role of threat in intergroup Relations. U. Wagner, L. R. Tropp, G. Finchilescu ve C. Tredoux (Ed.), Improving intergroup relations: Building on the legacy of Thomas F. Pettigrew içinde (s. 55-72). Malden: Blackwell Publishing.

Stephan, W. G., \& Stephan, C. W. (1985). Intergroup anxiety. Journal of Social Issues, 41(3), 157-175.

Stephan, W. G., Ybarra, O., \& Bachman, G. (1999). Prejudice toward immigrants. Journal of Applied Social Psychology, 29, 2221-2237.

Stephan, W. G., Ybarra, O., \& Rios, K. (2016). Intergroup threat theory. T. D. Nelson (Ed.), Handbook of prejudice, stereotyping, and discrimination içinde (s. 255-278). New York: Psychology Press.

Tajfel, H., \& Turner, J. C. (2004). The social identity theory of intergroup behavior. J. T. Jost ve J. Sidanius (Ed.), Political psychology: Key readings içinde (s. 367-390). New York: Psychology Press.

Verkuyten, M. (2006). Multicultural recognition and ethnic minority rights: A social identity perspective. European Review of Social Psychology, 17(01), 148-184.

Y1ldiz Nielsen, S. (2016). Perceptions between Syrians and their host community. Turkish Policy Quarterly, 15(3), 99-106. 


\section{Summary \\ Attitudes of University Students towards Syrians in Turkey: A Scale Development Study}

\author{
Hayriye Güleç ${ }^{1}$ \\ Bursa Uludağ University
}

\author{
Meltem Arslan Karaca² \\ Bursa Uludağ University
}

\author{
Gözde Başkaya ${ }^{3}$ \\ Bursa Uludağ University
}

\author{
Selçuk Karaca ${ }^{4}$ \\ Bursa Uludağ University
}

\author{
Nilay Kahraman ${ }^{5}$ \\ Bursa Uludağ University
}

In the refugee crisis following the civil war in Syria, Turkey has been the country accepting the highest number of Syrian refugees into its territory. According to the United Nations High Commissioner for Refugees, the number of Syrian refugees in Turkey was reported to be 3,541,572 as of July 19, 2018 (UNHCR, 2018).

Immigrants and refugees are mostly accepted as homogeneous groups and findings related to the attitudes of the individuals in the host countries towards migration are often generalized across the groups (Finney and Peach, 2004; Schweitzer, Perkoulidis, Krome, Ludlow, \& Ryan, 2005). Murray and Marx (2013) showed that the attitudes of Americans towards immigrants and asylum seekers who entered the country legally were more positive than immigrants who entered the country illegally. In another study, intergroup anxiety was associated with attitudes of Turks towards both immigrants and refugees, while pathogen-related disgust was associated only with attitudes towards refugees (Aral, Sevi ve Aydinli-Karakulak, 2016). These findings suggest that the status of the groups and the reasons for migration may affect the attitudes of the individuals in the host countries (Murray and Marx, 2013).

Turkey hosts the most refugees in the world (UNHCR, 2018). Attitudes towards Syrians in Turkey are mainly studied using opinion polls and in-depth interviews. In a study conducted by Hacettepe University Center for Migration Research in 11 provinces, almost half $(45.1 \%)$ of the respondents stated that they expect Syrians to return to their country (Erdoğan, 2014). The majority $(76.5 \%)$ considered that the presence of Syrians in Turkey would cause a significant social problem. (Erdoğan, 2014). Granting citizenship to Syrian refugees $(84.5 \%)$ was one of the most rejected issues (Erdoğan, 2014). In the 2015 report of Middle East Strategic Re- search Center, the negative attitudes towards Syrians were found to be about the differences in language, culture, and lifestyle, the concerns related to community peace and security, the restriction of job opportunities, and the capacity and service problems (Orhan and Senyücel Gündoğan, 2015).

Although opinion polls indicate that public attitudes towards Syrians are negative in Turkey, more systematical evaluation of these findings is required. The scales that were developed to examine attitudes towards Syrians mostly included items from other scales which measure attitudes towards immigrants in general rather than newly developed items specifically tailored to capture the Turkish context (Keles, December, Lightning, Kurtoğlu and Sunata, 2016). Besides, conceptual evaluation of the item content and factor structure of the newly developed scales were mostly lacking (Kılcan, Çepni and Kılınç, 2017; Köksal, Köksal and Köksal, 2017). The aim of this study is to develop the "Attitudes towards Syrians Scale". For this purpose, an item pool was prepared concerning Syrian refugees' adaptation and integration issues in Turkey and the psychometric properties of the scale was investigated in two studies conducted with university students. Also, the factor structure and item content of the scale were evaluated with respect to intergroup relations.

\section{Study I}

\section{Method}

Participants and Procedure. One hundred and eighty-four university students from Bursa Uludağ University participated in the study (Female: 101; Male: 83). The mean age of the participants was $21.94(\mathrm{SD}=2.75)$ years.

Address for Correspondence: Asst. Prof., Hayriye Güleç, Bursa Uludağ University, Faculty of Arts \& Sciences, Department of Psychology, Görükle Campus Nilüfer / Bursa

E-mail: hayriyegulec@uludag.edu.tr 
Attitudes towards Syrians Scale. An item pool consisting of 45 items was formed after reviewing the literature, and the written and oral media in the local and national press. After the initial inspection of the item pool, 34 items were accepted. Opinions from seven psychologists, two academicians, and one sociologist were obtained to examine the content validity of the scale. Eight more items were removed from the item pool using the formula proposed by Lawshe (1975). Following this procedure, the scale was administered to 25 psychology students at Bursa Uludağ University to examine the understandability and comprehensibility of the item pool. After deleting one item and rewriting four items, the final scale consisted of 25 items ( 8 positively and 17 negatively worded attitudes). Participants indicated their level of agreement with each item on a five-point Likert-type scale ("Strongly disagree", "Disagree", "Undecided", "Agree", "Strongly agree"). A minimum of 25 points and a maximum of 125 points were obtained from the scale. Higher scores indicated negative attitudes.

\section{Results}

Factor structure. Three factors were identified with eigenvalues greater than one. After deleting four items under multiple factors which had factor loading differences less than .10 , the total variance explained was calculated as $54.56 \%$. After rotation, the first factor explained about $20 \%$ of the variance, the second factor explained about $18 \%$ of the variance, and the third factor explained about $16 \%$ of the variance. Factor loadings varied between .54 and .78 .

Item-Total Correlations. Item-total correlations ranged between .40 and .74 and provided support for the item discrimination of the scale.

Internal Consistency. Cronbach's alpha coefficient for the total scale score was .93 and indicated perfect internal consistency of the scale.

\section{Discussion}

The first factor was composed of items related to intergroup anxiety and social dominance orientation. Intergroup anxiety is associated with avoidance and social distance from the outgroup (Stephan, Ybarra and Rios, 2016). Similarly, social dominance orientation is concerned with opposition to the equality of the groups and a tendency to maintain the superiority of the ingroup through unequal and dominance-based treatment of outgroup members (Sidanius and Pratto, 2004). Since intergroup anxiety and social dominance orientation are closely related to discriminatory behaviors, the first factor of the scale was identified as "discrimination".
The second and third factors of the scale were associated with realistic threats. According to Intergroup Threat Theory, realistic threats manifest themselves at the group and individual levels (Stephan, Renfro \& Davis, 2008). Perceived group threats are concerned with ingroup's power distance, access to resources and well-being as a whole. Whereas, realistic individual threats are concerned with perceived threats to the individual members of the ingroup. The second factor of the scale was associated with threat perception at the group level and identified as "realistic group threats". The third factor was associated with personal consequences of the threat and therefore, was identified as "realistic individual threats".

\section{Study II}

Previous studies indicated that perceived symbolic threats and attitudes towards diversity are associated with prejudice and discrimination against immigrants (Stephan, Ybarra and Rios, 2016; Verkuyten, 2006). To this end, two new items were added to the item pool. Besides, an item related to capacity and service-related attitudes was added to find out more about whether realistic threats are disaggregated between the group and individual levels. A second study was conducted to evaluate the factor structure of the scale.

\section{Method}

Participants and Procedure. Three hundred and seventeen university students from Bursa Uludağ University participated in the study (Female: 209; Male: 108). The mean age of the participants was 21.3 ( $\mathrm{SD}=$ 3.06) years.

Statistical Analysis. A two-step procedure was used to evaluate the factor structure of the scale. First, the data were split into two random sub-samples. Exploratory factor analysis was performed on the first random split-half. On the second random split-half, the fit of the scale was investigated using exploratory factor analysis conducted within the confirmatory factor analysis framework (Brown, 2006).

\section{Results}

Exploratory Factor Analysis. Data were analyzed for 165 randomly selected participants. Three factors were identified with eigenvalues greater than one. However, all but two items under one factor also loaded on other factors with factor loadings of .40 and above. Therefore, a two-factor solution was chosen in terms of parsimony. After repeating the analyses to extract two factors, the total variance explained was calculated as 
$55.85 \%$. The first factor explained approximately $31 \%$ of the variance, and the second factor explained approximately $25 \%$ of the variance. Factor loadings ranged between .53 and .87 . The internal consistency reliability coefficient calculated for the total scale score was .93.

Exploratory Factor Analysis Conducted Within The Confirmatory Factor Analysis Framework. Data were analyzed for 152 randomly selected participants. The fit of the model was acceptable (CFI $=.914$; TLI $=$ .901 ; RMSEA $=.077$; SRMR $=.069)$. The modification indices indicated that associating an item, which initially loaded under the second factor, with the first factor of the scale would improve the fit of the model (CFI = .936; TLI $=.926$; RMSEA $=.067$; SRMR $=.057)$. The item was replaced under the first factor as it was considered theoretically acceptable. Based on the modification indices, allowing the error variance of an item to covary with the error variances of two other items under the same factor would improve the fit of the model. Given the exploratory nature of the study, it was decided to remove the item from the scale. Removing the item improved the fit of the model better than allowing its error variance to covary with the other items. After these modifications, the model had good fit (CFI $=.958$; TLI $=.951$; RMSEA $=.055 ; \mathrm{SRMR}=.055$ ). The factor loadings ranged between .46 and .80 , and the factor loading of each item on its respective factor was statistically significant.

Item-Total Correlations. Item-total correlations ranged between .38 and .73 and provided support for the item discrimination of the scale.

Item-mean differences. According to the $t$ statistics, item-mean scores between the upper and lower $27 \%$ groups were significantly different at $\mathrm{p}<.001$ level.

Relationship between the "Threat Scale" and the "Attitudes towards Syrian Scale". The correlation between the total scale score and the Threat Scale (Karaoğlu, 2015) was positive and statistically significant $(\mathrm{r}(315)=.88, \mathrm{p}<.001)$.

Internal Consistency. Cronbach's alpha coefficient for the total scale score was .92 .

Descriptive Statistics. Participants tended to respond to the items associated with the first factor as "strongly disagree" and "disagree", whereas they responded to items related to the second factor as "strongly agree" and "agree".

\section{General Discussion}

In this study, the psychometric properties of the "Attitudes towards Syrians Scale" were investigated in two separate studies. The results indicated that the two-factor structure of the scale accounted for $56 \%$ of the total variance and had a good fit. Item-total correla- tions and statistically significant item-mean differences between the upper and lower $27 \%$ groups provided evidence for the item discrimination and validity of the scale. The Cronbach's alpha for the total scale score was .92 suggesting perfect internal consistency. The positive and significant correlation with the "Threat Scale" (Karaoğlu, 2015) demonstrated that both scales measured similar constructs, which provided evidence for the construct validity of the scale. According to these findings, the "Attitudes towards Syrians Scale" proved to be a reliable and valid instrument with sufficient psychometric properties.

The first factor of the scale included all the items observed in the first study, and similarly, it was defined as "discrimination". It consisted of items related to intergroup anxiety and social dominance orientation. The two factors of the first study, which were "realistic group threats" and "realistic individual threats", were reduced to a single factor. It was named as "realistic group and individual threats".

The participants' attitudes related to "discrimination" in both studies were more positive than their attitudes associated with "realistic threats". Although the self-reported attitudes of the participants did not indicate discriminatory behaviors, the fact that the positive attitude was not observed in terms of the perception of realistic threats prevents a conclusion that the attitudes towards Syrians were generally positive. Participants did not report blatant discrimination on items when social codes were clear (discrimination factor). However, they tended to favor the ingroup on items when social codes were not as clear (realistic threats factor). Further research is required to investigate whether attitudes of university students towards Syrians is expressed in the framework of subtle discrimination (Dovidio, Gaertner ve Pearson, 2016).

In conclusion, the findings of this study indicated that working on perceived realistic threats might contribute to reducing prejudice and discrimination against Syrians. The extent to which university students' emphasis on equality-based values is related to subtle discrimination should be investigated in further studies. The "Attitudes towards Syrians Scale", which proved to be a reliable and valid instrument can be utilized in the subsequent studies to measure the prejudice and discrimination against Syrians in Turkey. 